4

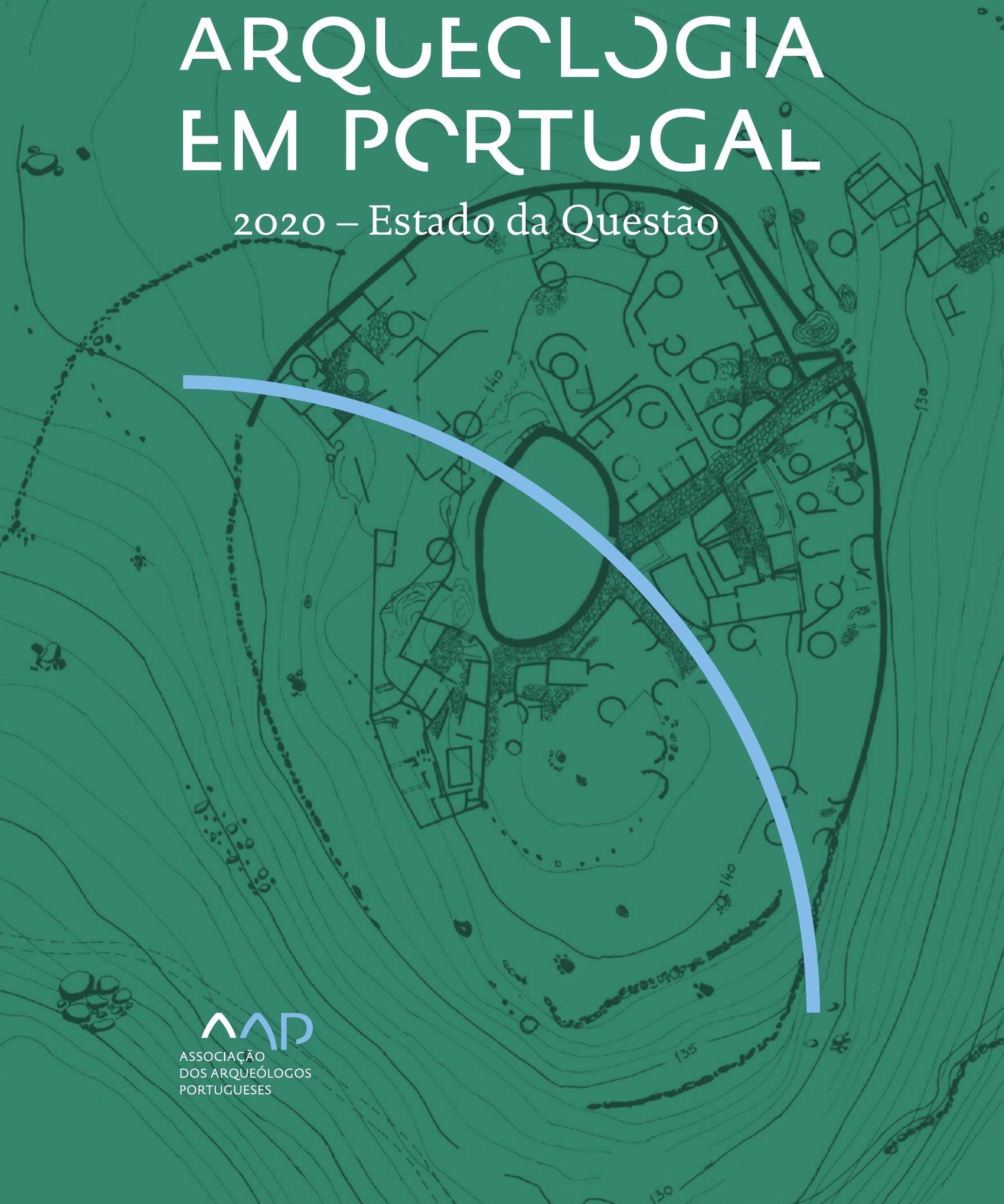


Coordenação editorial: José Morais Arnaud, César Neves e Andrea Martins Design gráfico: Flatland Design

AAP - ISBN: 978-972-9451-89-8

CITCEM - ISBN: 978-989-8970-25-1

Associação dos Arqueólogos Portugueses e CITCEM

Lisboa, 2020

O conteúdo dos artigos é da inteira responsabilidade dos autores. Sendo assim a Associação dos Arqueólogos Portugueses declina qualquer responsabilidade por eventuais equívocos ou questões de ordem ética e legal.

Desenho de capa:

Planta do castro de Monte Mozinho (Museu Municipal de Penafiel).

\section{$\hat{\wedge} \mathrm{P}$}

DOS ARQUEÓLOGOS PORTUGUESES

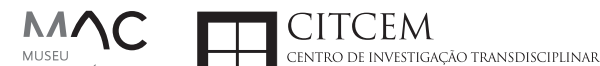
MUSEU
ARQUELLÓGICO
DO CARMO
U.PORTO

FLUP FACULDADE DE LETRAS
UNIVERSIDADE DO PORTO

Apoio

EC para a Ciência 


\section{Índice}

15 Prefácio

José Morais Arnaud

\section{Historiografia e Teoria}

17 Território, comunidade, memória e emoção: a contribuição da história da arqueologia (algumas primeiras e breves reflexões)

Ana Cristina Martins

25 Como descolonizar a arqueologia portuguesa?

Rui Gomes Coelho

41 Arqueologia e Modernidade: uma revisitação pessoal e breve de alguns aspetos da obra homónima de Julian Thomas de 2004

Vítor Oliveira Jorge

57 Dados para a História das Mulheres na Arqueologia portuguesa, dos finais do século XIX aos inícios do século XX: números, nomes e tabelas

Filipa Dimas / Mariana Diniz

73 Retractos da arqueologia portuguesa na imprensa: (in)visibilidades no feminino

Catarina Costeira / Elsa Luís

85 Arqueologia e Arqueólogos no Norte de Portugal Jacinta Bugalhão

101 Vieira Guimarães (1864-1939) e a arqueologia em Tomar: uma abordagem sobre o território e as gentes

João Amendoeira Peixoto / Ana Cristina Martins

115 Os memoráveis? A arqueologia algarvia na imprensa nacional e regional na presente centúria (2001-2019): características, visões do(s) passado(s) e a arqueologia

enquanto marca

Frederico Agosto / João Silva

129 A Evolução da Arqueologia Urbana e a Valorização Patrimonial no Barlavento Algarvio: Os casos de Portimão e Silves

Artur Mateus / Diogo Varandas / Rafael Boavida

\section{Gestão, Valorização e Salvaguarda do Património}

145 O Caderno Reivindicativo e as condições de trabalho em Arqueologia Miguel Rocha / Liliana Matias Carvalho / Regis Barbosa / Mauro Correia / Sara Simões / Jacinta Bugalhão / Sara Brito / Liliana Veríssimo Carvalho / Richard Peace / Pedro Peça / Cézer Santos

155 Os Estudos de Impacte Patrimonial como elemento para uma estratégia sustentável de minimização de impactes no âmbito de reconversões agrícolas Tiago do Pereiro

165 Salvaguarda de Património arqueológico em operações florestais: gestão e sensibilização Filipa Bragança / Gertrudes Zambujo / Sandra Lourenço / Belém Paiva / Carlos Banha / Frederico Tatá Regala / Helena Moura / Jacinta Bugalhão / João Marques / José Correia / Pedro Faria / Samuel Melro

179 Os valores do Património: uma investigação sobre os Sítios Pré-históricos de Arte Rupestre do Vale do Rio Côa e de Siega Verde José Paulo Francisco 
189 Conjugando recursos arqueológicos e naturais para potenciar as visitas ao Geoparque Litoral de Viana do Castelo (Noroeste de Portugal)

Hugo A. Sampaio / Ana M.S. Bettencourt / Susana Marinho / Ricardo Carvalhido

203 Áreas de Potencial Arqueológico na Região do Médio Tejo: Modelo Espacial Preditivo Rita Ferreira Anastácio / Ana Filipa Martins / Luiz Oosterbeek

223 Património Arqueológico e Gestão Territorial: O contributo da Arqueologia para a revisão do PDM de Avis

Ana Cristina Ribeiro

237 A coleção arqueológica do extinto Museu Municipal do Porto - Origens, Percursos e Estudos

Sónia Couto

251 Valpaços - uma nova carta arqueológica

Pedro Pereira / Maria de Fátima Casares Machado

263 Arqueologia na Cidade de Peniche

Adriano Constantino / Luís Rendeiro

273 Arqueologia Urbana: a cidade de Lagos como caso de Estudo Cátia Neto

285 Estratégias de promoção do património cultural subaquático nos Açores. O caso da ilha do Faial

José Luís Neto / José Bettencourt / Luís Borges / Pedro Parreira

297 Carta Arqueológica da Cidade Velha: Uma primeira abordagem

Jaylson Monteiro / Nireide Tavares / Sara da Veiga / Claudino Ramos / Edson Brito /

Carlos Carvalho / Francisco Moreira / Adalberto Tavares

311 Antropologia Virtual: novas metodologias para a análise morfológica e funcional Ricardo Miguel Godinho / Célia Gonçalves

\section{Didáctica da Arqueologia}

327 Como os projetos de Arqueologia podem contribuir para uma comunidade culturalmente mais consciente Alexandra Figueiredo / Claúdio Monteiro / Adolfo Silveira / Ricardo Lopes

337 Educação Patrimonial - Um cidadão esclarecido é um cidadão ativo! Ana Paula Almeida

351 A aproximação da Arqueologia à sala de aula: um caso de estudo no $3^{\circ}$ ciclo do Ensino Básico Luís Serrão Gil

363 Arqueologia 3.o - Pensar e comunicar a Arqueologia para um futuro sustentável Mónica Rolo

377 “Conversa de Arqueólogos" - Divulgar a Arqueologia em tempos de Pandemia Diogo Teixeira Dias

389 Escola Profissional de Arqueologia: desafios e oportunidades Susana Nunes / Dulcineia Pinto / Júlia Silva / Ana Mascarenhas

399 Os Museus de Arqueologia e os Jovens: a oferta educativa para o público adolescente Beatriz Correia Barata / Leonor Medeiros

411 O museu universitário como mediador entre a ciência e a sociedade: o exemplo da secção de arqueologia no Museu de História Natural e da Ciência da Universidade do Porto (MHNC-UP)

Rita Gaspar 
421 Museu de Lanifícios: Real Fábrica de Panos. Atividades no âmbito da Arqueologia Beatriz Correia Barata / Rita Salvado

427 Arqueologia Pública e o caso da localidade da Mata (Torres Novas) Cláudia Manso / Ana Rita Ferreira / Cristiana Ferreira / Vanessa Cardoso Antunes

431 Do sítio arqueológico ao museu: um percurso (também) didático Lídia Fernandes

447 Estão todos convidados para a Festa! E para dançar também... O projecto do Serviço Educativo do Museu Arqueológico do Carmo na $5^{\underline{a}}$ Edição da Festa da Arqueologia Rita Pires dos Santos

459 O “Clã de Carenque”, um projeto didático de arqueologia Eduardo Gonzalez Rocha

469 Mediação cultural: peixe que puxa carroça nas Ruínas Romanas de Troia Inês Vaz Pinto / Ana Patrícia Magalhães / Patrícia Brum / Filipa Santos

481 Didática Arqueológica, experiências do Projeto Mértola Vila Museu Maria de Fátima Palma / Clara Rodrigues / Susana Gómez / Lígia Rafael

\section{Arte Rupestre}

497 Os inventários de arte rupestre em Portugal Mila Simões de Abreu

513 O projeto FIRST-ART - conservação, documentação e gestão das primeiras manifestações de arte rupestre no Sudoeste da Península Ibérica: as grutas do Escoural e Maltravieso Sara Garcês / Hipólito Collado / José Julio García Arranz / Luiz Oosterbeek / António Carlos Silva / Pierluigi Rosina / Hugo Gomes / Anabela Borralheiro Pereira / George Nash / Esmeralda Gomes / Nelson Almeida / Carlos Carpetudo

523 Trabalhos de documentação de arte paleolítica realizados no âmbito do projeto PalæoCôa André Tomás Santos / António Fernando Barbosa / Luís Luís / Marcelo Silvestre / Thierry Aubry

537 Imagens fantasmagóricas, silhuetas elusivas: as figuras humanas na arte do Paleolítico Superior da região do Côa Mário Reis

$55^{1}$ Os motivos zoomórficos representados nas placas de tear de Vila Nova de São Pedro (Azambuja, Portugal) Andrea Martins / César Neves / José M. Arnaud / Mariana Diniz

571 Arte Rupestre do Monte de Góios (Lanhelas, Caminha). Síntese dos resultados dos trabalhos efectuados em 2007-2009 Mário Varela Gomes

599 Gravuras rupestres de barquiformes no Monte de S. Romão, Guimarães, Noroeste de Portugal Daniela Cardoso

613 Círculos segmentados gravados na Bacia do Rio Lima (Noroeste de Portugal): contributos para o seu estudo Diogo Marinho / Ana M.S. Bettencourt / Hugo Aluai Sampaio

631 Equídeos gravados no curso inferior do Rio Mouro, Monção (NW Portugal). Análise preliminar Coutinho, L.M. / Bettencourt, A.M.S / Sampaio, Hugo A.S

645 Paletas na Arte Rupestre do Noroeste de Portugal. Inventário preliminar Bruna Sousa Afonso / Ana M. S. Bettencourt / Hugo A. Sampaio 


\section{Pré-História}

661 O projeto Miño/Minho: balanço de quatro anos de trabalhos arqueológicos Sérgio Monteiro-Rodrigues / João Pedro Cunha-Ribeiro / Eduardo Méndez-Quintas / Carlos Ferreira / Pedro Xavier / José Meireles / Alberto Gomes / Manuel Santonja / Alfredo Pérez-González

677 A ocupação paleolítica da margem esquerda do Baixo Minho: a indústria lítica do sítio de Pedreiras 2 (Monção, Portugal) e a sua integração no contexto regional Carlos Ferreira / João Pedro Cunha-Ribeiro / Sérgio Monteiro-Rodrigues / Eduardo Méndez-Quintas / Pedro Xavier / José Meireles / Alberto Gomes / Manuel Santonja / Alfredo Pérez-González

693 O sítio acheulense do Plistocénico médio da Gruta da Aroeira Joan Daura / Montserrat Sanz / Filipa Rodrigues / Pedro Souto / João Zilhão

703 As sociedades neandertais no Barlavento algarvio: modelos preditivos com recurso aos SIG

Daniela Maio

715 A utilização de quartzo durante o Paleolítico Superior no território dos vales dos rios Vouga e Côa

Cristina Gameiro / Thierry Aubry / Bárbara Costa / Sérgio Gomes / Luís Luís / Carmen Manzano / André Tomás Santos

733 Uma perspetiva diacrónica da ocupação do concheiro do Cabeço da Amoreira (Muge, Portugal) a partir da tecnologia lítica Joana Belmiro / João Cascalheira / Célia Gonçalves

745 Novos dados sobre a Pré-história Antiga no concelho de Palmela. A intervenção arqueológica no sítio do Poceirão I

Michelle Teixeira Santos

757 Problemas em torno de Datas Absolutas Pré-Históricas no Norte do Alentejo Jorge de Oliveira

771 Povoamento pré-histórico nas áreas montanhosas do NO de Portugal: o Abrigo 1 de Vale de Cerdeira Pedro Xavier / José Meireles / Carlos Alves

783 Apreciação do povoamento do Neolítico Inicial na Baixa Bacia do Douro. A Lavra I (Serra da Aboboreira) como caso de estudo Maria de Jesus Sanches

797 O Processo de Neolitização na Plataforma do Mondego: os dados do Sector C do Outeiro dos Castelos de Beijós (Carregal do Sal)

João Carlos de Senna-Martinez / José Manuel Quintã Ventura / Andreia Carvalho / Cíntia Maurício

823 Novos trabalhos na Lapa da Bugalheira (Almonda, Torres Novas) Filipa Rodrigues / Pedro Souto / Artur Ferreira / Alexandre Varanda / Luís Gomes / Helena Gomes / João Zilhão

837 A pedra polida e afeiçoada do sítio do Neolítico médio da Moita do Ourives (Benavente, Portugal)

César Neves

857 Casal do Outeiro (Encarnação, Mafra): novos contributos para o conhecimento do povoamento do Neolítico final na Península de Lisboa.

Cátia Delicado / Carlos Maneira e Costa / Marta Miranda / Ana Catarina Sousa

873 Stresse infantil, morbilidade e mortalidade no sítio arqueológico do Neolítico Final/ Calcolítico ( $4^{\circ}$ e $3^{\circ}$ milénio a.C.) do Monte do Carrascal 2 (Ferreira do Alentejo, Beja) Liliana Matias de Carvalho / Sofia N. Wasterlain 
885 Come together: O Conjunto Megalítico das Motas (Monção, Viana do Castelo) e as expressões Campaniformes do Alto Minho Ana Catarina Basílio / Rui Ramos

899 Trabalhos arqueológicos no sítio Calcolítico da Pedreira do Poio Carla Magalhães / João Muralha / Mário Reis / António Batarda Fernandes

913 O sítio arqueológico de Castanheiro do Vento. Da arquitectura do sítio à arquitectura de um território João Muralha Cardoso

925 Estudo zooarqueológico das faunas do Calcolítico final de Vila Nova de São Pedro (Azambuja, Portugal): Campanhas de 2017 e 2018 Cleia Detry / Ana Catarina Francisco / Mariana Diniz / Andrea Martins / César Neves / José Morais Arnaud

943 As faunas depositadas no Museu Arqueológico do Carmo provenientes de Vila Nova de São Pedro (Azambuja): as campanhas de 1937 a 1967 Ana Catarina Francisco / Cleia Detry / César Neves / Andrea Martins / Mariana Diniz / José Morais Arnaud

959 Análise funcional de material lítico em sílex do castro de Vila Nova de S. Pedro (Azambuja, Portugal): uma primeira abordagem Rafael Lima

971 O recinto da Folha do Ouro 1 (Serpa) no contexto dos recintos de fossos calcolíticos alentejanos

António Carlos Valera / Tiago do Pereiro / Pedro Valério / António M. Monge Soares

\section{Proto-História}

987 Produção de sal marinho na Idade do Bronze do noroeste Português. Alguns dados para uma reflexão

Ana M. S. Bettencourt / Sara Luz / Nuno Oliveira / Pedro P. Simões / Maria Isabel C. Alves / Emílio Abad-Vidal

1001 A estátua-menir do Pedrão ou de São Bartolomeu do Mar (Esposende, noroeste de Portugal) no contexto arqueológico da fachada costeira de entre os rios Neiva e Cávado Ana M. S. Bettencourt / Manuel Santos-Estévez / Pedro Pimenta Simões / Luís Gonçalves

1015 O Castro do Muro (Vandoma/Baltar, Paredes) - notas para uma biografia de ocupação da Idade do Bronze à Idade Média

Maria Antónia D. Silva / Ana M. S. Bettencourt / António Manuel S. P. Silva / Natália Félix

1031 Do Bronze Final à Idade Média - continuidades e hiatos na ocupação de Povoados em Oliveira de Azeméis João Tiago Tavares / Adriaan de Man

1041 As faunas do final da Idade do Bronze no Sul de Portugal: leituras desde o Outeiro do Circo (Beja)

Nelson J. Almeida / Íris Dias / Cleia Detry / Eduardo Porfírio / Miguel Serra

1055 A Espada do Monte das Oliveiras (Serpa) - uma arma do Bronze Pleno do Sudoeste Rui M. G. Monge Soares / Pedro Valério / Mariana Nabais / António M. Monge Soares

1065 São Julião da Branca (Albergaria-a-Velha) - Investigação e valorização de um povoado do Bronze Final

António Manuel S. P. Silva / Paulo A. P. Lemos / Sara Almeida e Silva / Edite Martins de Sá

1083 Do castro de S. João ao Mosteiro de Santa Clara: notícia de uma intervenção arqueológica, em Vila do Conde Rui Pinheiro 
1095 O castro de Ovil (Espinho), um quarto de século de investigação - resultados e questões em aberto

Jorge Fernando Salvador / António Manuel S. P. Silva

1111 O Castro de Salreu (Estarreja), um povoado proto-histórico no litoral do Entre Douro e Vouga

Sara Almeida e Silva / António Manuel S. P. Silva / Paulo A. P. Lemos / Edite Martins de Sá

1127 Castro de Nossa Senhora das Necessidades (Sernancelhe): uma primeira análise artefactual Telma Susana O. Ribeiro

${ }_{1141}$ A cividade de Bagunte. O estado atual da investigação Pedro Brochado de Almeida

1153 Zoomorfos na cerâmica da Idade do Ferro no NW Peninsular: inventário, cronologias e significado Nuno Oliveira / Cristina Seoane

1163 Vasos gregos em Portugal: diferentes maneiras de contar a história do intercâmbio cultural na Idade do Ferro

Daniela Ferreira

1175 Os exotica da necrópole da Idade do Ferro do Olival do Senhor dos Mártires (Alcácer do Sal) no seu contexto regional

Francisco B. Gomes

\section{Antiguidade Clássica e Tardia}

1191 O uso de madeira como combustível no sítio da Quinta de Crestelos (Baixo Sabor): da Idade do Ferro à Romanização Filipe Vaz / João Tereso / Sérgio Simões Pereira / José Sastre / Javier Larrazabal Galarza / Susana Cosme / José António Pereira / Israel Espi

1207 Cultivos de Época Romana no Baixo Sabor: continuidade em tempos de mudança? João Pedro Tereso / Sérgio Simões Pereira / Filipe Santos / Luís Seabra / Filipe Vaz

1221 A casa romana na Hispânia: aplicação dos modelos itálicos nas províncias ibéricas Fernanda Magalhães / Diego Machado / Manuela Martins

1235 As pinturas murais romanas da Rua General Sousa Machado, n. ${ }^{5}$ 1, Chaves José Carvalho

1243 Trás do Castelo (Vale de Mir, Pegarinhos, Alijó) - Uma exploração agrícola romana do Douro

Tony Silvino / Pedro Pereira

1255 A sequência de ocupação no quadrante sudeste de Bracara Augusta: as transformações de uma unidade doméstica Lara Fernandes / Manuela Martins

1263 Os Mosaicos com decoração geométrica e geométrico-vegetalista dos sítios arqueológicos da área do Conuentus Bracaraugustanus. Novas abordagens quanto à conservação, restauro, decoração e datação Maria de Fátima Abraços / Licínia Wrench

1277 “Casa Romana” do Castro de São Domingos (Cristelos, Lousada): Escavação, Estudo e Musealização Paulo André de P. Lemos

1291 A arqueobotânica no Castro de Guifões (Matosinhos, Noroeste de Portugal): O primeiro estudo carpológico

Luís Seabra / Andreia Arezes / Catarina Magalhães / José Varela / João Pedro Tereso 
1305 Um Horreum Augustano na Foz do Douro (Monte do Castelo de Gaia, Vila Nova de Gaia) Rui Ramos

1311 Ponderais romanos na Lusitânia: padrões, formas, materiais e contextos de utilização Diego Barrios Rodríguez

1323 Um almofariz centro-itálico na foz do Mondego

Marco Penajoia

1335 Estruturas romanas de Carnide - Lisboa Luísa Batalha / Mário Monteiro / Guilherme Cardoso

1347 O contexto funerário do sector da "necrópole NO" da Rua das Portas de S. Antão (Lisboa): o espaço, os artefactos, os indivíduos e a sua interconectividade na interpretação do passado Sílvia Loja, José Carlos Quaresma, Nelson Cabaço, Marina Lourenço, Sílvia Casimiro, Rodrigo Banha da Silva, Francisca Alves-Cardoso

${ }_{1361}$ Povoamento em época Romana na Amadora - resultados de um projeto pluridisciplinar Gisela Encarnação / Vanessa Dias

1371 A Arquitectura Residencial em Mirobriga (Santiago do Cacém): contributo a partir de um estudo de caso Filipe Sousa / Catarina Felício

${ }_{1385}$ O fim do ciclo. Saneamento e gestão de resíduos nos edifícios termais de Mirobriga (Santiago do Cacém)

Catarina Felício / Filipe Sousa

1399 Balsa, Topografia e Urbanismo de uma Cidade Portuária Vítor Silva Dias / João Pedro Bernardes / Celso Candeias / Cristina Tété Garcia

1413 No Largo das Mouras Velhas em Faro (2017): novas evidências da necrópole norte de Ossonoba e da sua ocupação medieval Ricardo Costeira da Silva / Paulo Botelho / Fernando Santos / Liliana Nunes

1429 Instrumentos de pesca recuperados numa fábrica de salga em Ossonoba (Faro) Inês Rasteiro / Ricardo Costeira da Silva / Paulo Botelho

1439 A Necrópole Romana do Eirô, Duas Igrejas (Penafiel): intervenção arqueológica de 2016 Laura Sousa / Teresa Soeiro

1457 Ritual, descarte ou afetividade? A presença de Canis lupus familiaris na Necrópole Noroeste de Olisipo (Lisboa)

Beatriz Calapez Santos / Sofia Simões Pereira / Rodrigo Banha da Silva / Sílvia Casimiro / Cleia Detry / Francisca Alves Cardoso

1467 Dinâmicas económicas em Bracara na Antiguidade Tardia Diego Machado / Manuela Martins / Fernanda Magalhães / Natália Botica

1479 Cerâmicas e Vidros da Antiguidade Tardia do Edifício sob a Igreja do Bom Jesus (Vila Nova de Gaia) Joaquim Filipe Ramos

1493 Novos contributos para a topografia histórica de Mértola no período romano e na Antiguidade Tardia Virgílio Lopes

\section{8. Época Medieval}

1511 Cerâmicas islâmicas no Garb setentrional "português": algumas evidências e incógnitas Constança dos Santos / Helena Catarino / Susana Gómez / Maria José Gonçalves / Isabel Inácio / Gonçalo Lopes / Jacinta Bugalhão / Sandra Cavaco / Jaquelina Covaneiro / Isabel Cristina Fernandes / Ana Sofia Gomes 
1525 Contributo para o conhecimento da cosmética islâmica, em Silves, durante a Idade Média Rosa Varela Gomes

1537 Yábura e o seu território - uma análise histórico-arqueológica de Évora entre os séculos VIII-XII José Rui Santos

1547 A encosta sul do Castelo de Palmela - resultados preliminares da escavação arqueológica Luís Filipe Pereira / Michelle Teixeira Santos

1559 A igreja de São Lourenço (Mouraria, Lisboa): um conjunto de silos e de cerâmica medieval islâmica

Andreia Filipa Moreira Rodrigues

1571 O registo material de movimentações populacionais no Médio Tejo, durante os séculos XII-XIII. Dois casos de "sunken featured buildings", nos concelhos de Cartaxo e Torres Novas Marco Liberato / Helena Santos / Nuno Santos

1585 O nordeste transmontano nos alvores da Idade média. Notas para reflexão Ana Maria da Costa Oliveira

1601 Sepulturas escavadas na rocha do Norte de Portugal e do Vale do Douro: primeiros resultados do Projecto SER-NPVD

Mário Jorge Barroca / César Guedes / Andreia Arezes / Ana Maria Oliveira

1619 "Portucalem Castrum Novum" entre o Mediterrâneo e o Atlântico: o estudo dos materiais cerâmicos alto-medievais do arqueossítio da rua de D. Hugo, nํ. 5 (Porto) João Luís Veloso

1627 A Alta Idade Média na fronteira de Lafões: notas preliminares sobre a Arqueologia no Concelho de Vouzela

Manuel Luís Real / Catarina Tente

1641 Um conjunto cerâmico medieval fora de portas: um breve testemunho aveirense Susana Temudo

${ }_{1651}$ Os Lóios do Porto: uma perspetiva integrada no panorama funerário da Baixa Idade Média à Época Moderna em meios urbanos em Portugal

Ana Lema Seabra

1659 O Caminho Português Interior de Santiago como eixo viário na Idade Média Pedro Azevedo

1665 Morfologia Urbana: Um exercício em torno do Castelo de Ourém André Donas-Botto / Jaqueline Pereira

1677 Intervenção arqueológica na Rua Marquês de Pombal/Largo do Espírito Santo (Bucelas, Loures)

Florbela Estêvão / Nathalie Antunes-Ferreira / Dário Ramos Neves / Inês Lisboa

1691 O Cemitério Medieval do Poço do Borratém e a espacialidade funerária na cidade de Lisboa Inês Belém / Vanessa Filipe / Vasco Noronha Vieira / Sónia Ferro / Rodrigo Banha da Silva

1705 Um Espaço Funerário Conventual do séc. XV em Lisboa: o caso do Convento de São Domingos da Cidade Sérgio Pedroso / Sílvia Casimiro / Rodrigo Banha da Silva / Francisca Alves Cardoso

\section{9. Época Moderna e Contemporânea}

1721 Arqueologia Moderna em Portugal: algumas reflexões críticas em torno da quantificação de conjuntos cerâmicos e suas inferências históricas e antropológicas Rodrigo Banha da Silva / André Bargão / Sara da Cruz Ferreira

1733 Faianças de dois contextos entre os finais do século XVI e XVIII do Palácio dos Condes de Penafiel, Lisboa

Martim Lopes / Tomás Mesquita 
1747 Um perfil de consumo do século XVIII na foz do Tejo: O caso do Mercado da Ribeira, Lisboa Sara da Cruz Ferreira / Rodrigo Banha da Silva / André Bargão

1761 Os Cachimbos dos Séculos XVII e XVIII do Palácio Mesquitela e Convento dos Inglesinhos (Lisboa)

Inês Simão / Marina Pinto / João Pimenta / Sara da Cruz Ferreira / André Bargão / Rodrigo Banha da Silva

1775 "Tomar os fumos da erua que chamão em Portugal erua sancta». Estudo de Cachimbos provenientes da Rua do Terreiro do Trigo, Lisboa

Miguel Martins de Sousa / José Pedro Henriques / Vanessa Galiza Filipe

1787 Cachimbos de Barro Caulínitico da Sé da Cidade Velha (República de Cabo Verde)

Rodrigo Banha da Silva / João Pimenta / Clementino Amaro

1801 Algumas considerações sobre espólio não cerâmico recuperado no Largo de Jesus (Lisboa) Carlos Boavida

1815 Adereços de vidro, dos séculos XVI-XVIII, procedentes do antigo Convento de Santana de Lisboa (anéis, braceletes e contas)

Joana Gonçalves / Rosa Varela Gomes / Mário Varela Gomes

1837 Da ostentação, luxo e poder à simplicidade do uso quotidiano: arqueologia e simbologia de joias e adornos da Idade Moderna Portuguesa Jéssica Iglésias

1849 Os amuletos em Portugal - dos objetos às superstições: o coral vermelho Alexandra Vieira

1865 Cerâmicas de Vila Franca de Xira nos séculos XV e XVI Eva Pires

1879 «Não passa por teu o que me pertence». Marcas de individualização associadas a faianças do Convento de Nossa Senhora de Aracoeli, Alcácer do Sal Catarina Parreira / Íris Fragoso / Miguel Martins de Sousa

1891 Cerâmica de Leiria: alguns focos de produção

Jaqueline Pereira / André Donas-Botto

1901 Os Fornos na Rua da Biquinha, em Óbidos Hugo Silva / Filipe Oliveira

1909 A casa de Pêro Fernandes, contador dos contos de D. Manuel I: o sítio arqueológico da Silha do Alferes, Seixal (século XVI) Mariana Nunes Ferreira

1921 O Alto da Vigia (Sintra) e a vigilância e defesa da costa Alexandre Gonçalves / Sandra Santos

1937 O contexto da torre sineira da Igreja de Santa Maria de Loures Paulo Calaveira / Martim Lopes

1949 A Necrópole do Hospital Militar do Castelo de São Jorge e as práticas funerárias na Lisboa de Época Moderna Susana Henriques / Liliana Matias de Carvalho / Ana Amarante / Sofia N. Wasterlain

1963 SAND - Sarilhos Grandes Entre dois Mundos: o adro da Igreja e a Paleobiologia dos ossos humanos recuperados

Paula Alves Pereira / Roger Lee Jesus / Bruno M. Magalhães

1975 Expansão urbana da vila de Cascais no século XVII e XVIII: a intervenção arqueológica na Rua da Vitória no 15 a 17

Tiago Pereira / Vanessa Filipe

1987 Novos dados para o conhecimento do Urbanismo de Faro em época Moderna Ana Rosa 
1995 Um exemplo de Arqueologia Urbana em Alcoutim: o Antigo Edifício dos CTT Marco Fernandes / Marta Dias / Alexandra Gradim / Virgílio Lopes / Susana Gómez Martínez

2007 Palácio dos Ferrazes (Rua das Flores/Rua da Vitória, Porto): a cocheira de Domingos Oliveira Maia

Francisco Raimundo

2021 As muitas vidas de um edifício urbano: História, Arqueologia e Antropologia no antigo Recreatório Paroquial de Penafiel Helena Bernardo / Jorge Sampaio / Marta Borges

2035 O convento de Nossa Senhora da Esperança de Ponta Delgada: o contributo da arqueologia para o conhecimento de um monumento identitário João Gonçalves Araújo / N’Zinga Oliveira

2047 Arqueologia na ilha do Corvo... em busca da capela de Nossa Senhora do Rosário Tânia Manuel Casimiro / José Luís Neto / Luís Borges / Pedro Parreira

2059 Perdidos à vista da Costa. Trabalhos arqueológicos subaquáticos na Barra do Tejo Jorge Freire / José Bettencourt / Augusto Salgado

2071 Arqueologia marítima em Cabo Verde: enquadramento e primeiros resultados do projecto CONCHA

José Bettencourt / Adilson Dias / Carlos Lima / Christelle Chouzenoux / Cristóvão Fonseca / Dúnia Pereira / Gonçalo Lopes / Inês Coelho / Jaylson Monteiro / José Lima / Maria Eugénia Alves / Patrícia Carvalho / Tiago Silva

2085 Trabalhos arqueológicos na Cidade Velha (Ribeira Grande de Santiago, Cabo Verde): reflexões sobre um projecto de investigação e divulgação patrimonial André Teixeira / Jaylson Monteiro / Mariana Mateus / Nireide Tavares / Cristovão Fonseca / Gonçalo C. Lopes / Joana Bento Torres / Dúnia Pereira / André Bargão / Aurélie Mayer / Bruno Zélie / Carlos Lima / Christelle Chouzenoux / Inês Henriques / Inês Pinto Coelho / José Lima / Patrícia Carvalho / Tiago Silva

2103 A antiga fortificação de Quelba / Khor Kalba (E.A.U.). Resultados de quatro campanhas de escavações, problemáticas e perspectivas futuras Rui Carita / Rosa Varela Gomes / Mário Varela Gomes / Kamyar Kamyad

2123 Colónias para homens novos: arqueologia da colonização agrária fascista no noroeste ibérico Xurxo Ayán Vila / José Mạ . Señorán Martín 


\title{
PRODUÇÃO DE SAL MARINHO NA IDADE DO BRONZE DO NOROESTE PORTUGUÊS. ALGUNS DADOS PARA UMA REFLEXÃO
}

Ana M. S. Bettencourt ${ }^{1}$, Sara Luz ${ }^{2}$, Nuno Oliveira ${ }^{3}$; Pedro P. Simões ${ }^{4}$, Maria Isabel C. Alves ${ }^{4}$, Emílio Abad-Vidal ${ }^{5}$

\begin{abstract}
RESUMO
Os primeiros indícios da produção de sal no litoral norte de Portugal são, normalmente, atribuídos à Idade do Ferro. Contudo há evidências de que esta atividade se desenvolveu na região, pelo menos, entre os finais do $3^{\circ}$, início do $2^{\underline{0}}$ milénios $\mathrm{AC}$, tendo perdurando ao longo do $2^{\circ}$ milénio AC.

Apresentam-se dados provenientes de dois sítios arqueológicos e procede-se à reavaliação de artefactos descontextualizados encontrados no litoral - as designadas pias amovíveis - e de estruturas escavadas na rocha, discutindo-se as suas técnicas de execução. O conjunto de dados foi articulado com as condições naturais e topográficas da costa e com as condições climáticas conhecidas para a época. Foram, igualmente, articulados com as estratégias de ocupação durante a Idade do Bronze.
\end{abstract}

Palavras-chave: Noroeste Ibérico, Idade do Bronze, Produção de sal marinho.

\begin{abstract}
The first signs of salt production on the northern coast of Portugal are usually attributed to the Iron Age. However, there is evidence that this activity took place in the region at least between the late $3^{\text {rd }}$ millennium, early $2^{\text {nd }}$ millennium BCE.

Data from two archaeological sites are presented and the so-called removable sinks and the sinks excavated in the rock are re-evaluated. Their execution techniques are also discussed. The data set was articulated with the natural and topographic conditions of the coast and the known climatic conditions for the time. They were also articulated with the occupation strategies during the Bronze Age.
\end{abstract}

Keywords: Northwest of Iberian Peninsula, Bronze Age, Sea salt production.

\section{INTRODUÇÃO}

Os dados mais antigos sobre a produção de sal no ocidente da Península Ibérica remontam ao Neolítico e ao Calcolítico, embora sejam conhecidos apenas para o centro/sul de Portugal (Valera et alli, 2006; Rocha, 2013; Soares, 2013; Soares e Silva, 2013; Valera, 2017). Entre o Calcolítico Final e a Idade do
Bronze I, ou seja, entre os meados do $3^{\circ}$ milénio e os meados do $2^{\circ}$ milénio $\mathrm{AC}$, conhecem-se os sítios de Molino Sanchón II e Santioste (Abarquero et alli, 2010, 2013, 2017) localizados nos arredores do complexo lagunar de Villafáfila (Zamora, Espanha).

Para o Noroeste de Portugal apenas se conhecem algumas referências bibliográficas sobre a exploração do sal marinho, atribuídas sistematicamente à Idade

\footnotetext{
1. Laboratório de Paisagem, Património e Território (Lab2PT); Departamento de História da Universidade do Minho, Braga, Portugal. anabett@uaum.uminho.pt

2. Arqueóloga; Mestranda do Curso de Mestrado em Arqueologia da Universidade do Minho

3. Arqueólogo; Doutorando de Arqueologia da Universidade do Minho

4. Laboratório de Paisagem, Património e Território (Lab2PT); Instituto de Ciências da Terra, Polo da Universidade do Minho (ICT/ UM; Departamento de Ciências da Terra da Universidade do Minho

5. Fundación Centro de Supercomputación de Galicia (CESGA), Spain.
} 
do Ferro (Almeida, 1990, 1998, 2005; Costa et alli, 2012) com base na existência de pias cortadas nas rochas do litoral, bem como de pias amovíveis escavadas em lajes de rochas xistentas.

O achado de uma pia amovível em contexto arqueológico, observações sobre o modo como foram construídas as pias cortadas na rocha e novos achados arqueológicos, no litoral norte, possibilitam repensar a origem da produção de sal no Noroeste português e colocar a hipótese de que esta prática se terá iniciado, pelo menos, a partir da Idade do Bronze.

O presente trabalho teve, ainda, em conta, o contexto costeiro dos achados e a sua articulação quer com o povoamento deste período no litoral norte, quer com o que se sabe sobre as oscilações climáticas conhecidas para a Pré-história Recente.

\section{PIAS AMOVÍVEIS}

As pias amovíveis escavadas em lajes de rochas metamórficas, principalmente xistos, xistos ardosíferos e xistos mosqueados, são sempre pequenas e inferiores a 1 metro de comprimento (quando aparecem inteiras, o que é raro), sendo rodeadas por um rebordo perímetral. Podem ter contorno sub-retangular ou ovalar, cantos internos sempre arredondados e são muito baixas, com menos de $5 \mathrm{~cm}$ de profundidade. A largura da área escavada das que foi possível medir oscila entre os $22 \mathrm{e}$ os $35 \mathrm{~cm}$.

São muito comuns em algumas áreas do litoral do Noroeste português, sendo escassamente conhecidas na Galiza (Currás, 2019). Encontram-se, essencialmente descontextualizadas, no litoral caracterizado por praias arenosas de substrato rochoso frequentemente xistento. Aparecem, frequentemente, após as grandes marés equinociais de primavera e outono, sob as areias das praias. Tal significa que os seus contextos de origem, pela sua localização, estão atualmente, a ser destruídos pelos processos de erosão em curso (Figura 1).

Almeida (2005) refere o aparecimento destas pias nas praias situadas na fronteira entre as freguesias de Estela (Póvoa de Varzim) e da Apúlia (Esposende) e nas praias das freguesias de Marinhas, Belinho e da margem sul do rio Neiva, todas no concelho de Esposende. Trabalho de campo levado a cabo por um dos autores (AMS) detectou-as, especificamente, nas praias do Rio Alto, em frente ao Parque de Campismo, (freguesia da Estela, na Póvoa do Varzim); na praia da Ramalha (freguesia da Apúlia, Esposende); na praia da Robaleira e de Rio de Moinhos (na foz da Ribeira de Peralta) (ambas na freguesia de Marinhas, Esposende); na praia das Lontreiras (freguesia de São Bartolomeu do Mar); na praia de Sublago (freguesia de Belinho) e na praia de Guilheta (freguesia de São Paio de Antas) na foz do estuário do rio Neiva (Esposende). Na praia da Robaleira, fragmentos destas pias encontram-se na mesma área de um moinho manual de granito de grão fino (rocha inexistente no local) descoberto durante uma maré baixa no equinócio do outono de 2019. Mais a norte, no concelho de Viana do Castelo, foram também encontradas evidências destes objetos, em posição secundária, nas praias do Campo do Amo/Moinho da Moca (freguesia da Areosa) e de Carreço (na freguesia do mesmo nome). Já no concelho de Caminha regista-se a ocorrência de pias amovíveis nas atuais cascalheiras a norte do Forte da Lagarteira, em Vila Praia de Âncora, numa superfície com cerca de 200 metros (Figura 1).

A única encontrada in situ foi exumadas nas escavações arqueológicas realizadas por José Meireles Baptista, nos anos 8 o do século XX, a norte da praia de Carreço. Aí, foi detectada uma ocupação datada por termoluminescência da transição do $3^{\circ}$ para o $2^{\circ}$ milénio AC (Tabela 1).

Nesta, um fragmento de pia amovível em xisto mosqueado, jazia sobre um piso de seixos rolados que servia de base a uma grande estrutura de combustão (Figura 2). Neste local, então classificado como acampamento, não se detetaram recipientes cerâmicos, mas sim inúmeros artefactos líticos sobre seixos quartzíticos rolados, como pesos de redes, o que indicia a prática de atividades costeiras, como a pesca. Em contexto de reutilização as pias amovíveis ocorreram nos povoados proto-históricos de Santo António (freguesia da Afife, concelho de Viana do Castelo) (Oliveira e Bettencourt, 2020), de São Lourenço (freguesia de Vila Chã, concelho de Esposende) (Almeida, 1998) e de São Silvestre (freguesia de Cardielos, Viana do Castelo), este no estuário do rio Lima (Costa et alli, 2019). Terão aparecido, também, fragmentos destes objetos durante a escavação da Vila Tardo Romana da Agra do Relógio, em São Paio de Antas, Esposende, em contexto secundário (Costa et alli, 2019).

Embora tenham sido consideradas principalmente da Idade do Ferro (Almeida, 2005; Costa et alli, 2019), de acordo com os dados obtidos no acampamento de Carreço-praia, pode considerar-se que 
a extração de sal através da utilização de pias amovíveis ocorreu no Noroeste, pelo menos, desde o final do $3^{\circ}$ milénio até ao início do $2^{\circ}$ milénio AC. A sua associação com um moinho manual na praia da Robaleira indicia, também, a sua inserção na Pré-história Recente. A sua reutilização desde o final da Idade do Ferro (a partir do século II AC) deve ser considerada como o terminus do seu uso.

\section{PIAS ESCAVADAS NA ROCHA}

As pias escavadas na rocha constituem as evidências mais bem documentadas de extração de sal na costa atlântica do Noroeste português, ocorrendo na ordem dos milhares. Correspondem a pias de diferentes dimensões, contornos e profundidades, cortadas na parte mais elevada dos afloramentos rochosos. Estas estruturas são mais frequentes onde o substrato rochoso é preferencialmente granítico.

Podem aparecer isoladas, normalmente no topo de pequenos afloramentos; múltiplas mas dispersas pelo afloramento, ou em grupo e contíguas umas às outras. Tal é o caso dos núcleos de Fornelos (Costa et alli, 2019) e de Sinadora (inédito), em Viana do Castelo (Portugal).

As pias têm, principalmente, contornos ovais, trapezoidais ou rectangulares e os cantos sempre arredondados. Quando realizadas em espaços exíguos no topo de pequenos afloramentos tendem, por vezes, a adaptar-se à forma da superfície rochosa ou do espaço disponível, apresentando uma morfologia mais irregular. Podem assumir várias dimensões, sendo raras as que ultrapassam im de comprimento. São sempre muito pouco profundas (menos de $5 \mathrm{~cm}$ ).

A observação macroscópica de várias destas pias permitiu perceber que foram escavadas por percussão, possivelmente com martelos de pedra e depois polidas com seixos rolados, provavelmente misturados com areia para se tornarem mais abrasivos. Não parece ter sido usado o pico metálico na sua consecução escavação pois é frequente verificar-se que os grãos de quartzo, constituinte do granito local e existente no fundo das pias, não foram partidos. Os próprios cantos arredondados não indiciam o uso de instrumento metálico no seu fabrico.

Tal como as pias amovíveis, estas estruturas terão sido usadas para a produção de sal através da evaporação da água do mar.

Francisco Martins Sarmento faz-lhe uma primeira referência, em 1879, aquando de uma visita ao vale do
Âncora e à freguesia de Afife, considerando-as "gamelas naturais" (Sarmento, 1999). Posteriormente, Lemos (1982) encontra-as na área do Forte do Cão, na Gelfa, freguesia de Vila Praia de Âncora, concelho de Caminha, designando-as por "cuvetes". Apesar dos trabalhos de prospeção serem pouco abrangentes, conhecem-se pias cortadas na rocha desde a praia da Agudela, no concelho de Matosinhos, até às praias de Moledo, em Caminha (Bettencourt et alli, no prelo). São também conhecidas na Galiza, pelo menos até à ria de Vigo (Bettencourt et alii, no prelo).

Almeida (2005) refere a existência de núcleos na foz da Ribeira de Anha (freguesia de Darque, Viana do Castelo); entre a praia de Montedor ${ }^{6}$ e o Forte de Paçô (freguesia de Carreço, Viana do Castelo); no Forte Velho da Vinha (freguesias da Areosa, Viana do Castelo); no Forte do Cão e no Forte da Lagarteira (ambos em Vila Praia de Âncora, Caminha) e na praia de Moledo, em Caminha. O núcleo da Ribeira de Anha é também conhecido por praia da Foz do Rodanho.

Outros núcleos de pias encontram-se nas praias de Campo do Amo/Moinho do Moca, Gandaral, Corgo e Cobidalto (freguesia da Areosa, Viana do Castelo), inéditos; nas praias de Estremo ou Cão, Carrasquei$\mathrm{ra}^{7}$, Ínsua, Celeiro e Bico (freguesia de Afife, Viana do Castelo), inéditos; nas praias da Sarrosa (inédito) e de Canto Marinho, ambas em Carreço (Viana do Castelo) (Costa et alli, 2012); na área da capela de Santo Isidoro, praias da Estrada Real e Ribeira de Preces (Moledo, Caminha), também inéditas. Há ainda a notícia de que ocorrem na pequena ilha da Ínsua, Caminha, à foz do rio Minho, embora tal não tenha sido verificado (Figuras 1 e 3 ).

De destacar o núcleo de Canto Marinho que ocupa uma área de cerca de 24 ha e onde foram detetadas cerca de 713 pias (Costa et alli, 2012), na zona intertidal, indicando, segundo Carvalhido (2014 e 2018), que há cerca de 4 a 5 mil anos o nível do mar estaria 1 a 2 metros abaixo da posição atual.

Muitas destas estruturas estão atualmente localizadas na praia, ficando, portanto, submersas na maré cheia, o que atesta a sua antiguidade, algumas situam-se mais distantes do mar, embora sempre perto do litoral.

6. Conhecida, também, por praia de Fornelos.

7. De referir que Faria (2019), publica uma fotografia de uma pia salineira do sítio da Carrasqueira. 
A cronologia destas estruturas não é consensual. Almeida (2005) e Costa et alli (2012, 2019) consideram-nas da Idade do Ferro, quer pela sua proximidade espacial com povoados desse período, quer pelo espólio encontrado nas escavações de parte do conjunto de pias evolucionadas de Fornelos (Costa et alli, 2019). No entanto os artefactos aí encontrados não são conclusivos em termos cronológicos pois correspondem a picos em pedra lascada (certamente em posição secundária); restos de salinas amovíveis em xisto (conhecidas a poucas dezenas de metros na jazida de Carreço praia e datadas de entre o Calcolítico Final e os início da Idade do Bronze); pesos de rede sobre seixos rolados, existentes, pelo menos, desde os inícios da Idade do Bronze (Luz, 2020) até à Idade do Ferro (Martins, 1988, entre outros) e a escassíssimos fragmentos de cerâmica romana (um bordo de ânfora e tégula), materiais que, pelo tipo de salinas conhecidas para este período (Curras, 2017), só poderão corresponder a um terminus ante quem para o local. Assim, pelas suas condições de fabrico, pela similitude com as pias amovíveis e pela sua localização na linha da costa é possível colocar a hipótese de que a sua origem poderá remontar à Idade do Bronze regional, embora possam ter persistido ou sido reaproveitadas durante a Idade do Ferro. Também se deve salientar que existem povoados, entre muitos outros vestígios da Idade do Bronze, nas proximidades destas estruturas com as quais é possível estabelecer interligações espaciais.

\section{O SÍTIO ARQUEOLÓGICO DAS AREIAS ALTAS}

No sítio das Areias Altas, freguesia de Nevogilde, concelho do Porto, foram identificadas outras evidências arqueológicas que sugerem a produção de sal marinho na costa noroeste da Península Ibérica durante a Idade do Bronze.

O local situa-se entre os 21 e 23 metros acima do nível do mar e a cerca de 300 metros da linha de costa atual. A sua descoberta data do início dos anos 50 do século XX quando foi explorado, pela primeira vez, por Russell Cortez (1952, 1984). No contexto da arqueologia empresarial, entre 2008 e 2011, foram realizados novos trabalhos arqueológicos em áreas contíguas ao local, numa área de cerca de 3000 metros $^{2}$ (Figura 4). Neste âmbito foram escavadas mais de 200 estruturas em negativo, entre as quais se destaca um grande número de fossas, e alguns buracos de poste (Luz, 2010, 2020). Desde então, o sítio tem vindo a ser estudado por uma das autoras (SL), utilizando os dados obtidos nas intervenções designadas Areias Altas I e II como "janelas" para formular novas linhas de pesquisa, nomeadamente as que remetem para a produção de sal (Luz, 2020). As estruturas de tipo fossa apresentam, na sua maioria, um contorno subcircular, perfil esférico e base côncava ou aplanada. Em média, são bastante largas e pouco profundas $(140 \mathrm{~cm}$ de largura x $30 \mathrm{~cm}$ de profundidade) (Luz, 2020). Registou-se, ainda, um conjunto de estruturas de planta compósita que, aparentemente, não resultam da ocorrência de interseções. Assemelham-se a uma forma de " 8 " ou de um " 8 " com um pequeno semicírculo numa das extremidades, com a particularidade de cada segmento apresentar profundidades distintas (Luz, 202O).

Do enchimento das fossas recuperou-se grande quantidade de artefactos, entre outros restos materiais. Referimo-nos a recipientes de cerâmica, líticos, conchas e macrorrestos vegetais. A maioria dos fragmentos cerâmicos correspondem a recipientes de fabrico manual, pastas arenosas com numerosas inclusões de e.n.p. de grande calibre, friáveis, apresentando evidências de má cozedura, ao mesmo tempo que parecem ter sido sujeitos a tensões térmicas, o que poderá ter motivado o seu estado fragilizado e elevado nível de fragmentação. Em termos morfológicos apresentam perfis entre o cónico e o ovóide, bordos sumariamente regularizados e um pé alto com base plana, frequentemente alargada (Figura 4). Quanto às superfícies salienta-se um estado de conservação e tratamento desigual, apresentando-se as superfícies externas genericamente preservadas e rugosas, por oposição às internas, maioritariamente corroídas e com vestígios de alisamento e de maior cuidado, o que é particularmente evidente na parte interna das bases.

O restante conjunto cerâmico é constituído, na sua maioria, por recipientes de perfis tronco-cónicos, subcilíndricos e ovóides, de bases planas, muitas vezes providos de asas e com decoração plástica (cordões e mamilos). Ocorrem, ainda, formas carenadas que correspondem a raros exemplares de cerâmica fina. No seu conjunto, correspondem a formas que se enquadram no reportório cerâmico da Idade do Bronze do Noroeste de Portugal (Luz, 202O).

O conjunto lítico é composto, principalmente, por matérias-primas locais, predominando o quartzito $(55 \%)$, seguido do granito, do quartzo e do xisto, 
entre outras. É de salientar a presença de uma importante indústria macrolítica sobre seixos rolados e sobre lascas, nas quais se destacam pesos de rede, e onde se incluem raspadores e outros seixos talhados. Ocorre, ainda, uma pequena indústria em quartzo, alguns percutores, elementos de moinho e um artefacto em pedra polida, de anfibolito. Contudo a principal característica da amostra reflete-se na quantidade significativa de elementos termo-alterados $(65 \%)$, que indiciam a existência de lareiras ou de estruturas de combustão (Luz, 2020) (Figura 4). As datas de radiocarbono obtidas para este local situam a sua ocupação entre o séculos XIX e o final do XVI AC, ou seja, na primeira metade do $2^{\circ}$ milénio AC (Luz, 2010, 2020). As evidências arqueológicas e a localização do sítio permitem considerar que a produção de sal ocorreu nas Areias Altas (Luz, 2020), a par de outras atividades como a pesca e a recolha de moluscos (Luz, 2010; Cabral, 2010, 2014). Esta hipótese decorre, em primeiro lugar, dos atributos distintivos da cerâmica predominante - os vasos de pé alto, os quais são consonantes com a categoria de materiais de briquetage, definida por Gouletquer e Daire (1994, apud Téran, 2011). Deste modo, parece provável que tenham sido utilizados quer como moldes de sal cristalizado, em formas e pesos predefinidos, quer como recipientes onde se processou a cristalização através de uma fonte de calor ou por ação do fogo, tendo em conta a sua morfologia, tipo de fabrico, sinais de stress térmico e elevada fragmentação, uma vez que seria necessário parti-los para retirar o bolo de sal em bom estado. Segundo Cassen e Weller (2013), os recipientes de função dupla teriam de ser submetidos a fogo lento e prolongado para obter a cristalização e o endurecimento do sal, após o qual seriam partidos para retirar o "pão" de sal em bom estado. Estes recipientes encontram os seus melhores paralelos formais nos moldes de sal de sítios arqueológicos da Europa Central e Oriental, quer do Calcolítico da Roménia (meados do $5^{\circ}$ milénio a meados do $4^{\circ}$ milénio AC) (Cassen e Weller, 2013; Sandu et alli, 2012; Weller, 2015) quer da Idade do Bronze da Polónia (Harding, 2013).

Em segundo lugar, a forte evidência de estruturas de combustão atestada pelo elevado número de líticos termo-alterados, reforça a possibilidade da produção de "pães" de sal no local. É, no entanto, de considerar, que estas estruturas possam ter desempenhado outras funções dentro da cadeia operatória da produção de sal por evaporação artificial, a que se pode- rão associar outros artefactos e estruturas, ainda em fase de estudo.

\section{ALGUMAS CONSIDERAÇÕES FINAIS}

Tendo a conta os dados enunciados pode colocar-se a hipótese de que a produção de sal marinho se tenha verificado na área costeira do Noroeste português, desde, pelo menos, os finais do $3^{\circ}$ milénio $\mathrm{AC}$, tendo permanecido ativa durante a primeira metade do $2^{\circ}$ milénio AC.

É possível admitir que, desde essa data, a extração de sal foi realizada através do uso de pias amovíveis escavadas em rochas xistentas (Bettencourt, 2009). Tendo em conta o contexto da pia da estação arqueológica de Carreço-praia, tudo indica que estas estruturas, enchidas com água salgada ou de grande salinidade $^{8}$, teriam estado sobre a ação do fogo para favorecer o processo de evaporação da salmoura até à cristalização. De salientar que, durante os finais do $3^{\circ}$ e a primeira metade do $2^{\circ}$ milénios AC as comunidades humanas viveram num período mais frio do que atualmente, embora mais quente do que no Calcolítico (Fábregas Valcarce et alli, 2003; Martínez-Cortizas et alli, 2009) pelo que o processo de aquecimento das pias de xisto poderá ter sido uma das soluções encontradas para a evaporação da água salgada. A diminuição acentuada da humidade existente durante esse período (Fábregas Valcarce et alli, 2003; Martínez-Cortizas et alli, 2009) também poderá ter favorecido o processo de evaporação da água salgada.

A existência de pias amovíveis associadas espacialmente a um moinho manual de granito na praia da Robaleira (na zona intertidal) indiciam, igualmente, a antiguidade deste fenómeno. Assim, é de presumir que o processo de evaporação da água salgada através de pias amovíveis possa ter continuado durante todo ou grande parte da Idade do Bronze. Trata-se, na verdade, de um processo de evaporação simples ${ }^{9}$ e eficaz.

\footnotetext{
8. Eventualmente, proveniente de algumas lagoas costeiras com níveis variáveis de salinidade, típicos de períodos alternados de água doce e de água do mar (Granja et alli, 2010; Granja et alli, 2016), existentes num litoral rochoso e caraterizada por um sistema complexo de lagoas e de enseadas, ainda presente na época romana (Granja, 1993).

9. Cassen e Weller (2013) referem paralelos etnográficos similares na Europa e noutros continentes.
} 
As pias, escavadas nos afloramentos rochosos de composição granítica e metamórfica (micaxistos e gnaisses graníticos), são mais difíceis de datar mas as suas características de execução, a sua semelhança formal com as pias amovíveis e o facto de se localizarem frequentemente na zona intertidal ${ }^{10}$, são factores que possibilitam colocar a hipótese da sua antiguidade e da sua emergência em data anterior à Idade do Ferro. A partir de 1400 AC, verifica-se um aquecimento acentuado da temperatura do ar (Fábregas Valcarce et alli, 2003; Martínez-Cortizas et alli, 2009) o que teria facilitado a evaporação da água salgada das referidas pias por insolação e ação eólica ${ }^{11}$, no entanto não podemos excluir a contemporaneidade entre as pias amovíveis e as pias escavadas na rocha, podendo ambas corresponderem a diferentes etapas do processo de produção de sal.

Durante a Idade do Bronze, a natureza rochosa e topográfica da costa portuguesa (mais recortada na altura), seria favorável à produção de sal, assim como algumas características climáticas. Referimo-nos, por exemplo, à descida acentuada e progressiva da humidade do ar, entre $2200 \mathrm{AC}$ até cerca de 1600 AC, acompanhada de uma ligeira subida da temperatura, importante durante a fase de degradação das condições climáticas que caracterizou o período entre os finais do IV e os meados do II milénios AC, assim como ao facto de este período genérico ser mais ventoso do que anteriormente (Fábregas Valcarce $e t$ alli, 2003; Martínez-Cortizas et alli, 2009). A partir de cerca de 1400 AC, verifica-se um aumento acentuado da temperatura do ar, tal como já foi referido, fenómeno que é acompanhado da subida da humi-

10. Se tivermos em conta os estudos de Granja (1992), Granja e Carvalho (1992, 1995), Alves (1996), Granja e Groot (1996) e Granja (1999) terão ocorrido modificações drásticas no litoral norte durante o Holocénico, ao contrário do proposto por Dias (1987) e Dias e Boski (1995) que defendem a estabilidade do nível do mar, a cotas próximas da atual, em cerca de $6 \mathrm{Ka}$ (4ํㅡㄹ milénio AC). Granja (1999) propõe que, durante essa data, o nível médio do mar estaria a cerca de 8 metros abaixo do atual, embora tendo em conta a atividade neotectónica existiriam, nessa altura, médias de levantamento a rondar os $3 \mathrm{~mm} /$ ano, com tendência a abrandar para 1.4 $\mathrm{mm} / \mathrm{ano}$, em cerca de $1500 \mathrm{AC}(3.5 \mathrm{Ka})$. Carvalhido (2018, p. 17) admite que o nível do mar estaria 1 a 2 metros mais baixo, há cerca de 5 a $4 \mathrm{Ka}$ ( $3^{\circ}$ e $2^{\circ}$ milénios $\left.\mathrm{AC}\right)$.

11. Pias salineiras similares são conhecidas em rochas calcárias, em diversas áreas geográficas, e usadas até à contemporaneidade. A este propósito consultar a síntese sobre o tema da autoria de Cassen e Weller (2013). dade, até valores próximos dos atuais, situação que permanecerá até aos meados do ํㅜ milénio AC.

Significativa é, também, a concentração de povoados e de outras manifestações da Idade do Bronze ao longo da costa do Noroeste de Portugal, fenómeno que, entre outros factores, se poderá relacionar com a exploração de sal na área costeira. Esta hipótese, já defendida para explicar o povoamento deste período na área de entre os rios Neiva e Cávado (Bettencourt, 1999: 1078), parece ser possível de equacionar, igualmente, para a Galiza, onde, por exemplo, as populações do povoado costeiro de Portocelo, datado de entre os séculos XV aos início do XII AC (Cano Pan e Vázquez Varela, 1988) teriam acesso, no seu território teórico de exploração de 15, 30 e 45 minutos, a diferentes núcleos de pias salineiras (Bettencourt et alli, no prelo).

Em Portugal há evidências, a partir do Bronze Inicial/Médio, de vários povoados, necrópoles, depósitos, estátuas-menires e gravuras rupestres em localização costeira com acesso facilitado às áreas com evidências de exploração de sal, embora, para sul do Cávado, seja necessário intensificar a prospecção no sentido de detetar novos núcleos de pias salineiras. Entre os rios Minho e Lima conhecem-se o povoado do Bronze Final do Coto da Pena, (Caminha), à foz do Coura, em pleno estuário do Minho; as gravuras rupestre da Bouça dos Feitos I (Riba de Âncora, Caminha), com um punhal longo ou espada curta, do Bronze Inicial (Bettencourt, 2017); o povoado da Idade do Bronze do Lombo da Enxurreira (Vile, Caminha), perto da foz do Âncora (Loureiro e Magalhães, 2006); as gravuras rupestres de Santo Adrião (Âncora, Caminha), com armas e barquiformes (Santos-Estévez, Bettencourt, 2017); o povoado do Bronze Final de Santo António (Viana do Castelo), à foz do rio de Cabanas (Bettencourt, 2013a) com acesso a inúmeras pias salineiras no seu território teórico de 15 a 6 o minutos terrestres (Oliveira e Bettencourt, 2020) (Fig. 5); as gravuras rupestres da Laje da Churra (Carreço, Viana do Castelo), com uma alabarda e inúmeros barquiformes (Santos, 2014); o túmulo da Cova da Moura (Carreço, Viana do Castelo) onde se depositou um artefacto metálico do Bronze Final (Viana, 1955; Bettencourt, 2013a) e o depósito metálico de machados de talão do Bronze Final do Cobidalto/Areosa (Areosa, Viana do Castelo) (Monteagudo 1977; Bettencourt et alii, 2014). Entre os rios Lima e Cávado conhecem-se as reutilizações do Bronze Inicial/Médio e Final da Ma- 
moa do Lordelo de Cima (Chafé, Viana do Castelo) (Bettencourt, 2010a); a necrópole do Bronze Médio/Final de Agra de Antas (São Paio de Antas, Esposende) (Cruz e Gonçalves, 1998/1999; Bettencourt, 1999); a necrópole do Bronze Médio de Belinho (São Paio de Antas, Esposende) (Bettencourt, 1999); os achados metálicos do Bronze Inicial/Médio do Monte de Sanfins (Belinho/São Bartolomeu do Mar, Esposende) (Bettencourt e Sampaio, 2017); a estátua menir do Pedrão (São Bartolomeu do Mar, Esposende) (Jorge, Baptista, Gonçalves, 1986; Bettencourt et alli, 2020); as reutilizações do Bronze Inicial/Médio das Mamoas da Serra, Antela da Portelagem e Rapido (Esposende) (Bettencourt, 1999; 2013b); o povoado do Bronze Final de São Lourenço (Esposende) (Bettencourt, 1999), com acesso no seu território de 45 a 60 minutos, a várias áreas onde ocorrem pias amovíveis (Figura 5) e a necrópole do Bronze Inicial/Médio da Cavaleira (Esposende) (Almeida, 1988; Bettencourt, 1999, 2011).

Entre o rio Cávado e o Douro há a registar o possível povoado do Bronze Médio do Monte do Terroso (Póvoa de Varzim) (Bettencourt, 2011; Sampaio, 2014); o povoado da Idade do Bronze de Santa Clara (Vila do Conde) ${ }^{12}$, à foz do Ave, margem norte; o povoado do Corgo (Azurara, Vila do Conde), do Bronze Médio, entre outras possíveis ocupações (Bettencourt, 2013b; Sampaio, 2014), à foz do Ave, margem sul; o povoado do Bronze Médio de Lavra (Matosinhos) com acesso, no seu território de exploração de 30 minutos pedestres, às pias salineiras de Agudela (Bettencourt et alli, no prelo) (Fig. 5); a ocupação da Idade do Bronze sob as areias da praia do Fontão/ Angeiras (Lavra, Matosinhos) (Bettencourt, 2010b); o povoado da Idade do Bronze de Monte Douro (Perafita, Matosinhos) (Pires, 2012, p. 56); o povoado da Idade do Bronze de Gatões (Matosinhos), à foz do Leça (Barbosa, 2016) que, pelas características da cerâmica se poderá inserir no Bronze Inicial/Médio, ao qual se deve acrescentar o sítio das Areias Altas (Porto) (Luz, 2010; 2020).

Perante este conjunto de dados é verosímil aceitar que o processo de evaporação da água salgada através de pias cortadas nas rochas ou de pias amovíveis, bem como a produção de bolos de sal, pode ter sido uma atividade importante e especializada ao longo da Idade do Bronze do litoral do noroeste

12. Informação gentilmente cedida por José Carvalho da Omniknos Arqueologia. português. Aliás esta região continuou a produzir sal durante a época romana, como o demonstram os achados das salinas de Angeiras (Lavra, Matosinhos) (Teixeira e Fonseca, 2011; Currás, 2017) e de muitas outras, inéditas, existentes no litoral dos concelhos de Viana do Castelo e de Caminha, similares às escavadas no decorrer do projeto Mar de Sal, no sudoeste da Galiza (Currás, 2017). Esta atividade persiste durante a Idade Média (Almeida, 2005; Currás, 2017), começando a decrescer a partir dos séculos XIV e XV (Rau, 1951) embora a atividade se mantenha, como residual, até aos séculos XVIII e XIX (Marçal, 1966; Fernandes, 1994).

\section{AGRADECIMENTOS E APOIOS}

Os autores agradecem a Horácio Faria e a José Varela algumas informações prestadas. Este trabalho foi realizado no âmbito dos seguintes projetos: Funerary, ceremonial and other practices between the $\mathrm{Ne}$ olithic and the Bronze Age approached by Archaeometry (ARQUEOM Project-Sept2O14), desenvolvido por AMSB, PPS e MICA; A Idade do Ferro do litoral Norte entre as bacias dos rios Minho e Cávado. Materialidades, intercâmbios e traços de identidade (ref. $\mathrm{SFRH} / 138105 / 2018)$, da responsabilidade de $\mathrm{NO}$ e O sítio das Areias Altas, Porto, no contexto da Idade do Bronze do Norte de Portugal, em desenvolvimento por S. Luz.

\section{BIBLIOGRAFIA}

ABARQUERO MORAS, Francisco J.; GUERRA DOCE, Elisa; DELIBES DE CASTRO, Gérman; LÓPEZ SÁEZ, José A. (2017) - La explotación de la sal durante la Prehistoria en las Lagunas de Villafáfila (Zamora): los cocederos de Molino Sanchón II y Santioste. Cuaternario y Geomorfología. 31: 1-2, pp. 7-24.

ABARQUERO MORAS, Francisco J.; GUERRA DOCE, Elisa; DELIBES DE CASTRO, Gérman; PALOMINO LÁZARO, Ángel L.; DEL VAL RECIO, Jesús (2010) - Excaviones en los "cocederos" de sal prehistóricos de Molino Sanchón II y Santioste (Villafáfila, Zamora). In: ABARQUERO, Francisco J.; GUERRA Elisa, eds. - Los yacimientos de Villafáfila (Zamora) en el marco de las explotaciones salineras de la prehistoria europea. Valladolid: Junta de Castilla y Léon, pp. 85-118.

ABARQUERO MORAS, Francisco J.; GUERRA DOCE, Elisa; DELIBES DE CASTRO, Gérman; PALOMINO LÁZARO, Ángel L.; DEL VAL RECIO, Jesús (2013) - Explorações pré-históricas de sal nos arredores das lagunas de Villafáfila (Zamora, Espanha). In: SOARES, Joaquina, ed. 
- Pré-história das zonas húmidas. Paisagens de sal (Setúbal Arqueológica 14). Setúbal: MAEDS, pp. 233-254.

ALMEIDA, Carlos Alberto B. (1988) - Carta Arqueológica do Concelho de Esposende, Boletim Cultural de Esposende 13/14. pp. 21-44.

ALMEIDA, Carlos Alberto B. (1990) - Proto-História e Romanização da Bacia Inferior do Lima. Viana do Castelo: Centro de Estudos Regionais.

ALMEIDA, Carlos Alberto B. (1998) - Esposende. Povoamento Romano do Litoral Minhoto entre o Cávado e o Minho (Boletim Cultural de Esposende, 20). Esposende: Câmara Municipal de Esposende.

ALMEIDA, Carlos Alberto B. (2005) - A exploração do sal na costa portuguesa a Norte do Rio Ave: da Antiguidade Clássica à Baixa Idade Média. In: Amorin, Inês ed. - Seminário Internacional sobre o Sal Português, 2004, Porto: Instituto de História Moderna, pp. 139-170.

ALVES, António M.C. (1996) - Causas e Processos da Dinâmica Sedimentar na Evolução Actual do Litoral do Alto Minho. Braga: Universidade do Minho.

BARBOSA, Liliana (2016) - O Lugar de Gatões (Matosinhos). Uma perspectiva diacrónica da ocupação do local, comunicação apresentada no evento A Arqueologia em Portugal. Recuperar o passado em 2015, disponível em linha em https://www.academia.edu/33242725/

BAPTISTA, José M. (1992) - As Indústrias Líticas Pré-Históricas do Litoral Minhoto. Contexto Cronoestratigráfico e Paleoambiental (Cadernos de Arqueologia - Monografias, 7). Braga: Unidade de Arqueologia da Universidade do Minho.

BETTENCOURT, Ana M.S. (1999) - A Paisagem e o Homem na bacia do Cávado durante o II e I milénios AC. Braga: Universidade do Minho.

BETTENCOURT, Ana M.S. (2009) - A Pré-História do Minho: do Neolítico à Idade do Bronze. In: PEREIRA, Paulo ed. - Minho. Traços de Identidade. Braga: Conselho Cultural da Universidade do Minho, pp. 70-113.

BETTENCOURT, Ana M.S. (2010a) - La Edad del Bronce en el Noroeste de la Península Ibérica: una análisis a partir de las prácticas funerárias. Trabajos de Prehistoria. 67:1, pp. 139-173.

BETTENCOURT, Ana M.S. (2010b) - Comunidades pré-históricas da bacia do Leça. In: VARELA, José; PIRES, Conceição, eds. - O Rio da Memória: Arqueologia no Território do Leça. Matosinhos: Câmara Municipal, pp. 33-88.

BETTENCOURT, Ana M.S. (2011) - Estruturas e práticas funerárias do Bronze Inicial e Médio do Noroeste Peninsular. In: BUENO, Primitiva; GILMAN, Antonio; MARTÍN MORALES, Concha; SÁNCHEZ-PALENCIA, Francisco J., eds. - Arqueología, Sociedad, Territorio y Paisaje (Bibliotheca Praehistorica Hispana 27). Madrid: CSIC, pp. 115-139.
BETTENCOURT, Ana M.S. (2013a) - O Bronze Final no Noroeste português. Uma rede complexa de lugares, memórias e ações. Estudos Arqueológicos de Oeiras. 20: pp. 157-172.

BETTENCOURT, Ana M.S. (2013b) - A Pré-história do Noroeste Português / The Prehistory of the North-western Portugal, Territórios da Pré-história em Portugal, vol. 2, Braga / Tomar: CEIPHAR/CITCEM (E. bilingue).

BETTENCOURT, Ana M.S. (2017) - Gravuras rupestres do noroeste português para além das artes atlântica e esquemática, In: ARNAUD, José. M.; MARTINS, Andrea, eds. Arqueologia em Portugal - 2017. Estado da Questão, Lisboa: Associação dos Arqueólogos Portugueses, pp. 1039-105.

BETTENCOURT, Ana M.S.; SAMPAIO, Hugo A. (2017) The Middle and the beginning of the Late Bronze Age in the Northwestern Iberia, In: LACHENAL, Thibault; MORDANT, Claude; NICOLAS, Théophane; VÉBER Cécile, eds. - Le Bronze moyen et l'origine du Bronze final en Europe occidentale (XVII ${ }^{-}$-XIII ${ }^{e}$ siècle av. J.-C.) (Monographies d'Archéologie du Grand Est 1), Strasbourg: APRAB, pp. 365-385.

BETTENCOURT, Ana M.S.; COMENDADOR REY, Beatriz; SIMÕES, Pedro P.; ALVES, Maria Isabel C. (2014). O depósito de machados do Bronze Final de Cobidalto, Areosa (Viana do Castelo). Novos dados para a sua contextualização e interpretação. In: BETTENCOURT, Ana M.S.; COMENDADOR REY, Beatriz; SAMPAIO, Hugo A.; SÁ, Edite, eds. - Corpos e Metais na Fachada Atlântica da Ibéria. Do Neolítico à Idade do Bronze. Braga: APEQ, CITCEM, pp. 131-142.

BETTENCOURT, Ana M.S.; SANTOS-ESTÉVEZ, Manuel; GONÇALVES, Luís; SIMÕES, Pedro, P. (2020) - A Estátua-Menir do Pedrão ou de São Bartolomeu do Mar (Esposende, Noroeste de Portugal) no contexto arqueológico da fachada costeira de entre os rios Neiva e Cávado. In: Arqueologia em Portugal / 2020 - Estado da Questão, Lisboa, pp. 17-30.

BETTENCOURT, A.M.S.; LUZ, Sara; SIMÕES, Pedro P.; ALVES, Maria Isabel C.; ABAD-VIDAL, Emilio (no prelo) - Bronze Age sea salt production in Northwest Iberian Peninsula. In MARCIGNY Cyril; MORDANT, Claude, eds. Bronze 2019: 20 ans de recherches, Dijon: Suppléments au Bulletin de l'APRAB.

CABRAL, João P. (2010) - O depósito de conchas do sítio arqueológico das Areias Altas (Porto, Portugal). Estudo morfológico e morfométrico das conchas inteiras de moluscos. In GÓMEZ, Eduardo G.; GARCÍA, Víctor B.; RODRÍGUEZ, Carlos F.; PRIETO, Nativida F. eds. - I Reunión Científica de Arqueomalacología de la Península Ibérica (Férvedes 6): Villalba: MPAV, pp. 73-82.

CABRAL, João P. (2014) - Morfologia das conchas de Phorcus Lineatus (da Costa 1778: Trochus) do sítio arqueológico de Areias Altas II (Porto, Portugal) e seu possível significado ambiental, In CANTILLO, Juán J.; BERNAL, Darío; RAMOS, José eds. - Actas de la $3^{\circ}$ Reunión Científica de Arqueomalacología de la Península Ibérica: 65-74. Cádiz: Universidad de Cádiz, Servicio de Publicaciones, pp. 65-74. 
CANO PAN, Juan A.; VÁZQUEZ VARELA, José M. (1988) - Portocelo, un yacimiento de la Edad del Bronce. Trabalhos de Antropologia e Etnologia. 28, pp. 181-187.

CARVALHIDO, Ricardo (2018) - Livro de pedra. Monumentos naturais locais de Viana do Castelo - catálogo. Viana do Castelo: Câmara Municipal.

CASSEN, Serge; WELLER, Olivié, (2013) - Idées et faites relatifs à la production de sels marins et terrestres en Europe, du VI ${ }^{\mathrm{e}}$ au III ${ }^{\mathrm{e}}$ millénnaire. In: SOARES, Joaquina, ed. - Prehistory of wetlands: Ladscapes of salt. (Setúbal Arqueológica, 14). Setúbal: MAEDS, pp. 255-304.

COSTA, Miguel; MACHADO, Jorge; LOPES, Hugo; ALMEIDA, Tiago (2012) - Pias salineiras da praia do Canto Marinho. Inventário Arqueológico, Cadernos Vianenses, 46, pp. 95-111.

COSTA, Miguel; ALMEIDA, Tiago; MACHADO, Jorge (2019) - A exploração de sal na Proto-História. O exemplo de Viana do Castelo, comunicação apresentada nos Encontros monográficos co património Cultural in situ. A prudoción de sal en época romana no sur de Galicia e Norte de Portugal, A Guarda, March 29th, 2019 (disponível em https://www. youtube.com/watch?v=leDyyodniAM in 1/4/2020).

CORTEZ, Fernando R. (1952) - Contributos para o estudo do Neolítico de Portugal. Trabalhos de Antropologia e Etnologia. 13:3-4, pp. 193-248.

CORTEZ, Fernando R. (1984) - Achados pré-históricos na área do Porto. Arqueologia.10, pp. 11-12.

CURRÁS, Brais X. (2017) - The salinae of O Areal (Vigo) and Roman salt production in NW Iberia, Journal of Roman archaeology, 30:1, pp. 325-350.

CRUZ, Domingo J.; GONÇALVES, António H.B. (1998/ 1999) - A necrópole de Agra de Antas (S. Paio de Antas, Esposende, Braga. Portugália. 19-20, pp. 5-27.

DIAS, João Manuel A.; BOSKI, Thomasz (1995) - Shoreline Evolution in Portugal since the Last Glacial Maximum: A review of current knowledge. IGCP Project. In: 367 Annual Meeting - Late Quaternary Coastal Records of Rapid Change: Application to Present and Future Conditions. Abstracts. Chile: Antofagasta, pp. 29-30.

DIAS, João Manuel A. (1987) - Dinâmica Sedimentar e Evolução Recente da Plataforma Continental Portuguesa Setentrional. Lisboa: Universidade de Lisboa.

DIAS, João Manuel A.; RODRIGUES, Aurora; MAGALHÃES, Fernando (1997) - Evolução da linha de costa em Portugal desde o último Máximo Glaciário até à actualidade: síntese dos conhecimentos. Estudos do Quaternário. 1, pp. 53-66.

FABREGAS VALCARCE, Ramón; MARTÍNEZ CORTIZAS, António; BLANCO CHAO, Ramón; CHESWORTH, Ward (2003) - Environmental change and social dynamics in the second-third millennium BC in NW Iberia. Journal of Archaeological Science. 30, pp. 859-871.
FARIA, Horácio (2019) - Martins Sarmento e as pesquisas arqueológicas em Afife. Revista Estudos Regionais. $2^{\underline{\underline{a}}}$ série, 13, pp. 77-117.

FERNANDES, Armando (1994) - Meadela Histórica, Paróquia de Santa Cristina da Meadela. Viana do Castelo: ed. autor.

GRANJA Helena M. (1992) - Zona costeira: evolução e ordenamento. Geonovas, no especial 1, 57-63.

GRANJA, Helena (1993) - Os conhecimentos actuais sobre o Holocénico do Noroeste de Portugal. In CARVALHO, Gaspar S., FERREIRA António B., SENNA-MARTINEZ, João C., eds. - O Quaternário em Portugal. Balanço e Perspectivas. Lisboa: Colibri, pp. 43-49.

GRANJA, Helena (1999) - Evidence for Late Pleistocene and Holocene sea level, neotectonic and climatic control in the coastal zone of Northwest Portugal. Geologie en Mijnbouw. 77:3-4, pp. 233-245.

GRANJA, Helena; CARVALHO, Gaspar S. (1992) - Dunes and Holocene deposits of the coastal zone of Portugal, North Mondego Cape. In: CARTER, Richard W.G.; CURTINS, Tom G.F.; SHEEHY-SKEFFINGTON, Michelin J. (eds) - Coastal Dunes: Geomorphology, Ecology and Management for Conservation. Rotterdam: Balkema, pp. 43-50.

GRANJA, Helena e CARVALHO, Gaspar S. (1995) - Sealevel changes during the Pleistocene-Holocene in the NW coastal zone of Portugal. Terra Nova. 7, pp. 6o-67.

GRANJA, Helena; de GROOT, Thomas A.M. (1996) - Sealevel rise and neotectonism in a Holocene coastal environment at Cortegaça, a beach (NW Portugal): a case study. Journal of Coastal Research.12, pp. 160-170.

GRANJA, Helena; MONTEIRO-RODRIGUES, Sérgio; DANIELSEN, Randi (2016) - Changing environments and human settlement during Mid-Holocene in Rio de Moinhos beach (Esposende, Northern Portugal). Estudos do Quaternário. 14, pp. 25-40.

GRANJA, Helena; ROCHA, Fernando; MATIAS, Manuel; MOURA, Rui; CALDAS, Francisco; MARQUES, Joana; TARECO, Hélder (2010) - Lagoa da Apúlia: A residual lagoon from the Late Holocene (NW coastal zone of Portugal). Quaternary International. 221, pp. 46-57.

GOULETQUER, Pierre L.; DAIRE, Marie Y. (1994) - Le sel de la Préhistoire et de la Protohistoire. In DAIRE, Marie Y., ed. - Le sel Gaulois. Bouilleurs de sel et ateliers de briquetages armoricains à l’Age du Fer. Saint-Malo: CNRS, pp. 5-13.

HARDING, Anthony (2013) - Salt in Prehistoric Europe. Leiden: Sidestone Press.

JORGE, Vítor O.; BAPTISTA, António M.; GONÇALVES, António A.H.B. (1986) - Menir de S. Bartolomeu do Mar (Esposende), Boletim Cultural de Esposende. 9-10: 13-20.

LEMOS, Francisco S., O Sítio Arqueológico de Gelfa. Notícia preliminar, Cadernos de Arqueologia. 1ํㅗérie, 2, pp. 21-48. 
LOUREIRO, Luís; MAGALHÃES, Ivone (2006) - O Lugar da Idade do Bronze do Lombo da Enxurreira (Riba de Âncora, Caminha), Al-Madan Online. 2ª série, 14, pp. 29-32.

LUZ, Sara (2010) - O depósito de conchas do sítio arqueológico das Areias Altas (Porto, Portugal). Discussão do enquadramento arqueológico da Estrutura 15. In GÓMEZ, Eduardo G.; GARCÍA, Víctor B.; RODRÍGUEZ, Carlos F.; PRIETO, Nativida, eds. - I Reunión Científica de Arqueomalacología de la Península Ibérica (Férvedes 6). Villalba: MPAV, pp. 141-145.

LUZ, Sara (2020) - The site of Areias Altas (Porto, Portugal): current knowledge of its occupation in the first half of the 2nd millennium BC. In LOPES, Susana S.; GOMES, Sérgio, eds. - Between the $3^{\text {rd }}$ and $2^{\text {nd }}$ millennia BC: which turning points? Oxford: Archaeopress.

MARÇAL, Horácio (1966) - As antigas salinas da Terra de Bouça. Matosinhos: Biblioteca Pública Municipal de Matosinhos.

MARTINS, Maria Manuela R. (1988) - A citânia de S. Julião, Vila Verde. Memória dos trabalhos realizados entre 1981 e 1985. (Cadernos de Arqueologia - Monografias 2.) Braga: Universidade do Minho.

MARTÍNEZ CORTIZAS, António; COSTA-CASAIS, Manuela; LOPEZ-SAEZ, José A. (2009) - Environmental change in NW Iberia between 7000 and 500 cal. BC. Quaternary International. 200, pp.77-89.

MONTEAGUDO, Luís (1977) - Die Beile auf der Iberischen Halbinsel. Prähistorische Bronzefunde. Munich: Mann Verlag. Refs: 1034, 1057, 1061, 1089, 1111, 1121, 1481, 1489.

OLIVEIRA, Nuno; BETTENCOURT, Ana M.S. (2020) - O povoado de Santo António (Afife, Viana do Castelo), na Idade do Bronze Final, Antrope 13 (no prelo).

PIRES, Conceição (2012) - Contributos para o estudo do povoamento do concelho de Matosinhos da Pré-história ao séc. VIII. Porto: Faculdade de Letras da Universidade do Porto.

ROCHA, Leonor (2013) - A praia do Forte Novo. Um sítio de produção de sal na costa Algarvia? In SOARES, Joaquina, ed. - Prehistory of wetlands. Ladscapes of salt. (Setúbal Arqueológica 14). Setúbal: MAEDS, pp. 225-232.

RAU, Virgínia (1951) - A exploração e o comércio do sal de Setúbal, Lisboa: Ed. Autor.

SAMPAIO, Hugo A. (2014) - A Idade do Bronze na Bacia do Ave (Noroeste de Portugal), Braga: Universidade do Minho.

SANDU, Ion; WELLER, Olivier; STUMBEA, Dan; ALEXIANU, Marius (2012) - Analyses archéométriques sur les moules à sel chalcolithiques de l'est de la Roumanie. In: NIKOLOV, Vassil; BACVAROV, Krum, eds. - Salt and gold: the role of salt in Prehistoric Europe. Verliko Tarnovo, pp. 143-154.
SANTOS, Ana C. (2014) - A Laje da Churra (Paçô, Carreço, Viana do Castelo). Braga: Universidade do Minho.

SANTOS-ESTÉVEZ, Manuel; BETTENCOURT, Ana M. S. (2017) - O conjunto de gravuras rupestres de Santo Adrião (Caminha, Portugal). Embarcações, armas, cavalos e ex-votos. In: ARNAUD, José M.; MARTINS Andrea, eds. Arqueologia em Portugal - 2017. Estado da Questão. Lisboa: Associação dos Arqueólogos Portugueses, pp. 1055-1070.

SARMENTO, Francisco Martins (1999) - Antiqua. Apontamentos de Arqueologia. Guimarães: Sociedade Martins Sarmento.

SOARES, Joaquina (2013) - Sal e conchas na Pré-história portuguesa. O povoado da Ponta da Passadeira (estuário do Tejo). In: SOARES, Joaquina, ed. - Prehistory of wetlands. Ladscapes of salt (Setúbal Arqueológica 14). Setúbal: MAEDS, pp. 171-196.

SOARES, Joaquina; SILVA, Carlos T. (2013) - Economia agro-marítima na Pré-história do estuário do Sado. Novos dados sobre o Neolítico da Comporta. In: SOARES, Joaquina, ed. - Prehistory of wetlands. Ladscapes of salt. (Setúbal Arqueológica 14). Setúbal: MAEDS, pp. 145-170.

TEIXEIRA, Ricardo; FONSECA Vítor (2011) - Intervenção arqueológica. Requalificação da Orla Costeira de Matosinhos, Matosinhos: Arqueologia e Património, Lda. (Relatório Técnico Científico).

TERÁN MANRIQUE, Jonathan (2011) - La producción de sal en la prehistoria de la Península Ibérica: estado de la cuestión. Arqueología y Territorio. 8, pp.71-84.

VALERA, António Carlos (2017) - Salt in the $4^{\text {th }}$ and $3^{\text {rd }}$ millennia BC in Portugal: specialization, distribution and consumption. Cuaternario y Geomorfología. 31:1-2. pp.105-122.

VALERA, António Carlos; TERESO, João P.; REBUGE, João (2006) - O Monte da Quinta 2 (Benavente) e a produção no Neolítico Final/Calcolítico do estuário do Tejo. In BICHO, Nuno F.; VERÍSSIMO, Hugo, eds. - Do Epipaleolítico ao Calcolítico na Península Ibérica. Actas do IV Congresso de Arqueologia Peninsular (Promontória Monográfica 4). Faro: Universidade do Algarve, pp. 201-305.

VIANA, Abel (1955) - A Cova da Moura. Crónica do III Congresso Nacional de Arqueologia. Zaragoza, pp. 481-497.

WELLER, Olivier (2015) - First salt making in Europe: an overview since Neolithic times. Documenta Praehistorica. 62, pp. $185-196$. 


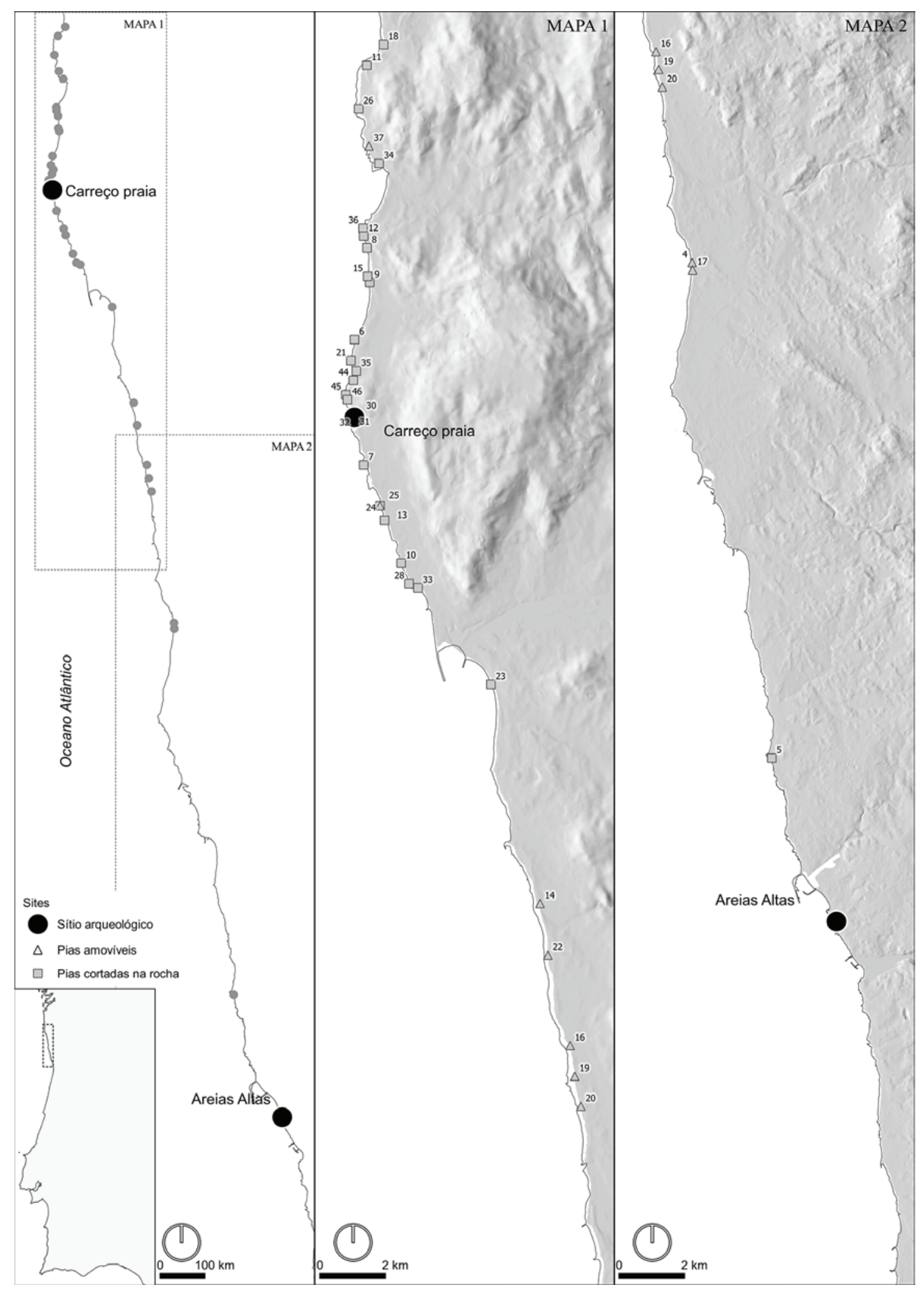

Figura 1 - Localização dos sítios arqueológicos associados à produção de sal, citados no texto (Bettencourt et alii, no prelo, adaptado). Mapa 1: área entre os rios Minho e Lima: 6 - Bico; 7 - Canto Marinho; 8 - Carrasqueira; 9 - Celeiro; 10 - Corgo; 11 - Estrada Real; 12 - Estremo ou Cão; 13 - Gandaral; 15 - Ínsua; 18 - Preces; 21 - Sarrosa; 24/25 - Campo do Amo/Moinho do Moca; 26 - Santo Isidoro; 28 - Cobidalto; 29 - Fornelos 1; 30 - Fornelos 2; 31 - Fornelos 3; 32 - Fornelos 4; 33 - Forte Velho da Vinha; 34 - Forte da Lagarteira; 35 - Forte de Paçô; 36 - Forte do Cão; 37 -Lagarteira; 40 - Outeiro Pequeno; 43-Sarrido; 44-Sinadora 1; 45-Sinadora 2; 46-Sinadora; Mapa 2: área entre os rios Lima e Douro: 4-Ramalha; 5-Agudela; 14-Guilheta; 16 - Lontreiras; 17-Rio Alto; 19 - Rio de Moinhos; 20 - Robaleira; 22 - Sublago; 23 - Foz do Rodanho. 


\begin{tabular}{|l|l|l|l|l|}
\hline Estação arqueológica & Tipo de data & Data (BP) & Cal AC (2 sigma) & Referência \\
\hline Carreço Praia & $\begin{array}{l}\text { Termoluminescência } \\
\text { média }\end{array}$ & $3855 \pm 207$ & 2280 (1865) 1450 & Baptista, 1992 \\
\hline
\end{tabular}

Tabela 1
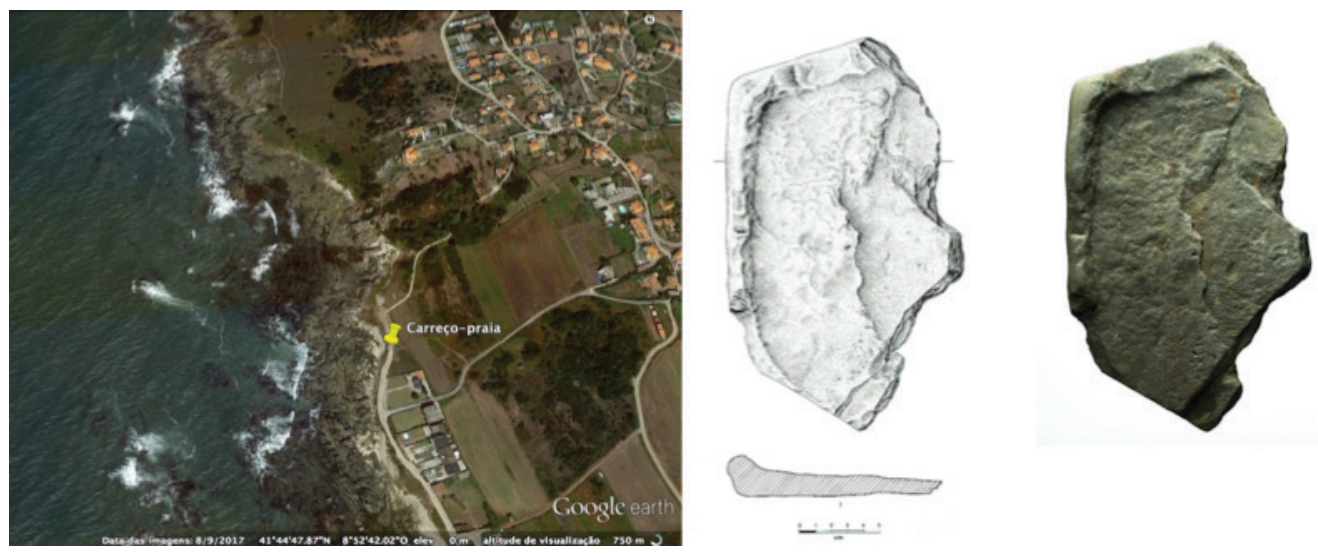

Figura 2 - Localização da estação de Carreço-praia e pia salineira aí encontrada.
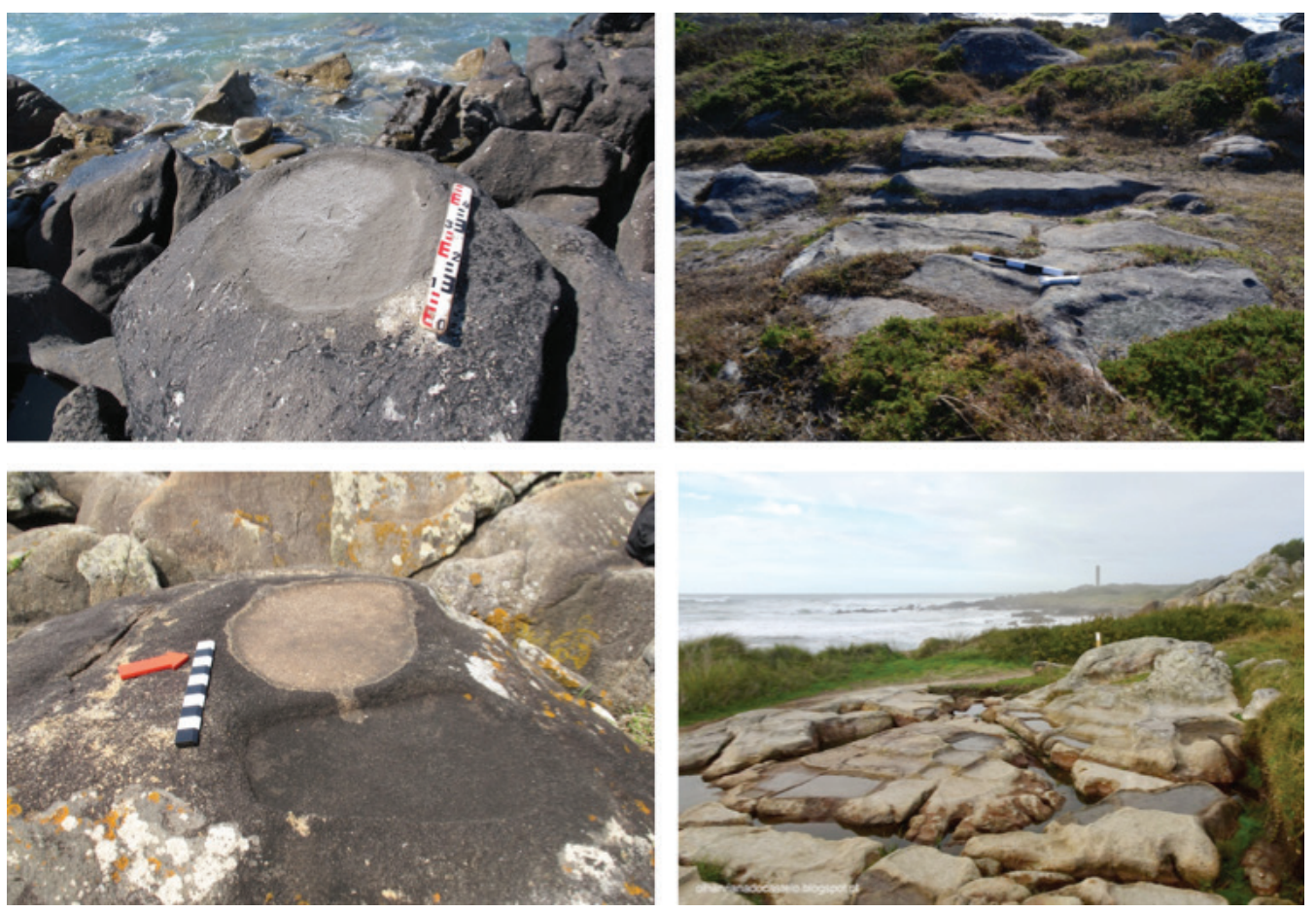

Figura 3 - Pias de vários locais do litoral norte: Em cima (da esquerda para a direita) Forte do Cão e núcleo das imediações do Forte de Paçô. Em baixo (da esquerda para a direita): Sinadora e núcleo de Fornelos (fonte de Fornelos: https://olharvianadocastelo.blogspot.com/2018/12/viana-marcas-dopassado.html) 

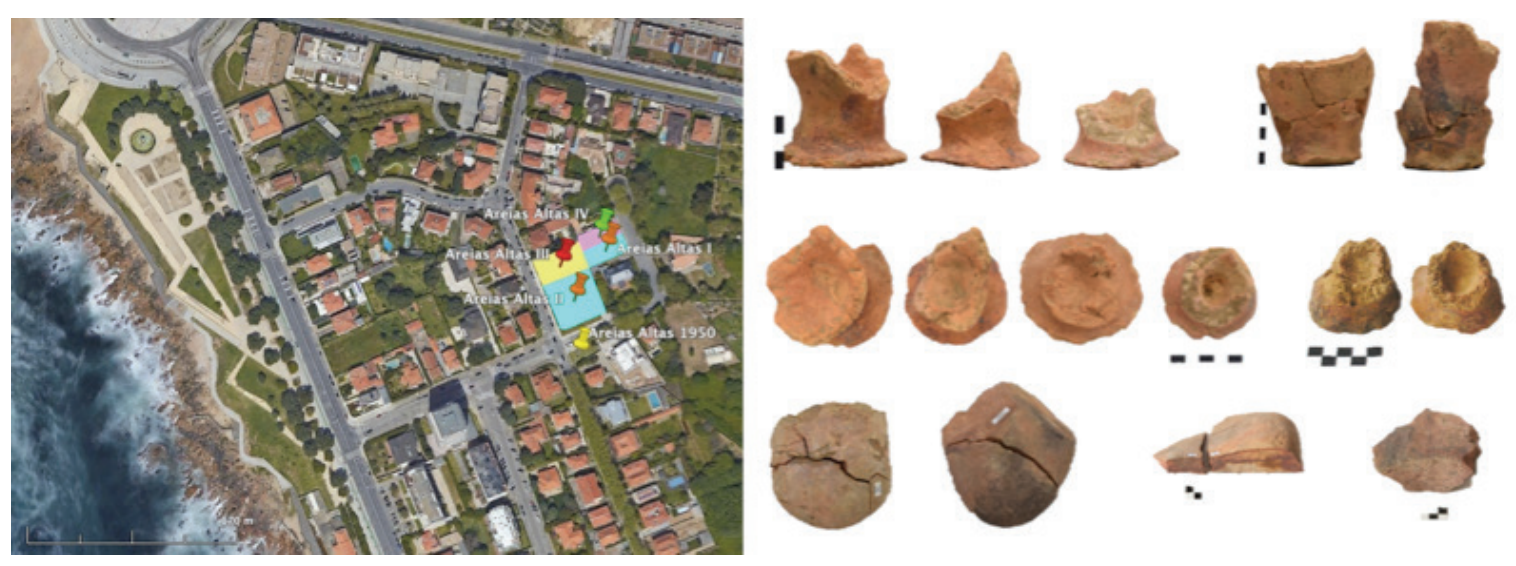

Figura 4 - Localização das Areias Altas; fragmentos de recipientes de pé alto, de vasos tronco-cónicos e de seixos rolados termo-alterados. 


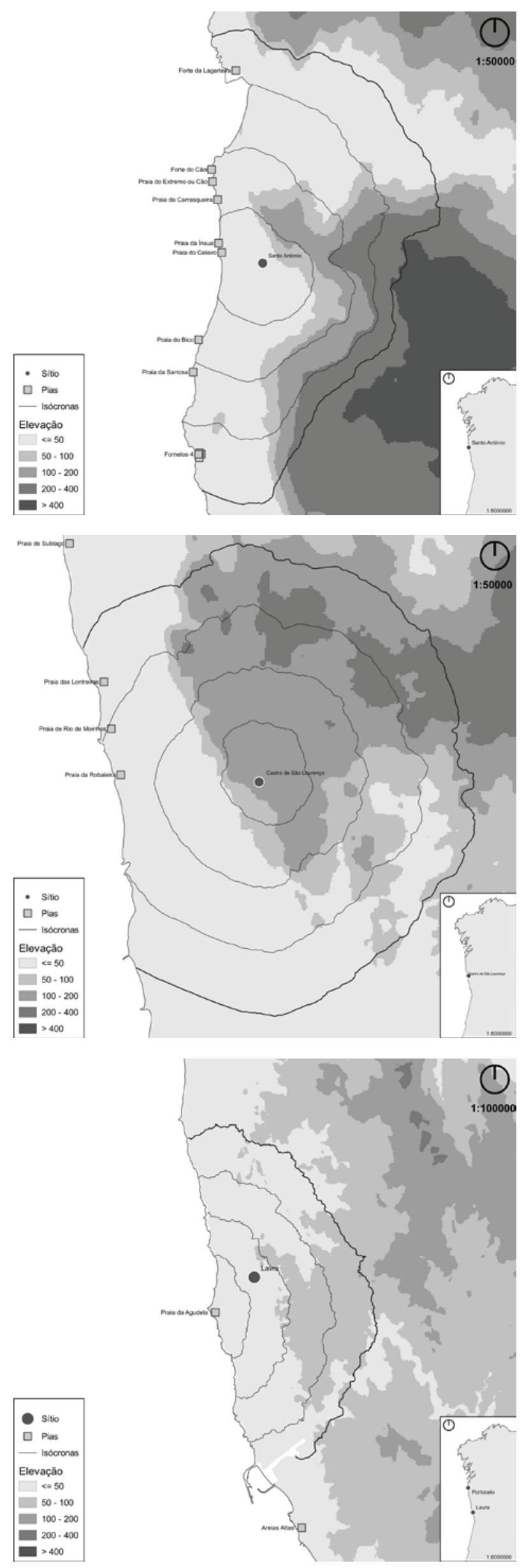

Figura 5 - Territórios teóricos de 60 minutos dos povoados de Santo António (Oliveira, Bettencourt, 2020), de São Lourenço e de Lavra (Bettencourt et alii, no prelo, adaptado), face às estruturas conhecidas para produção de sal. 



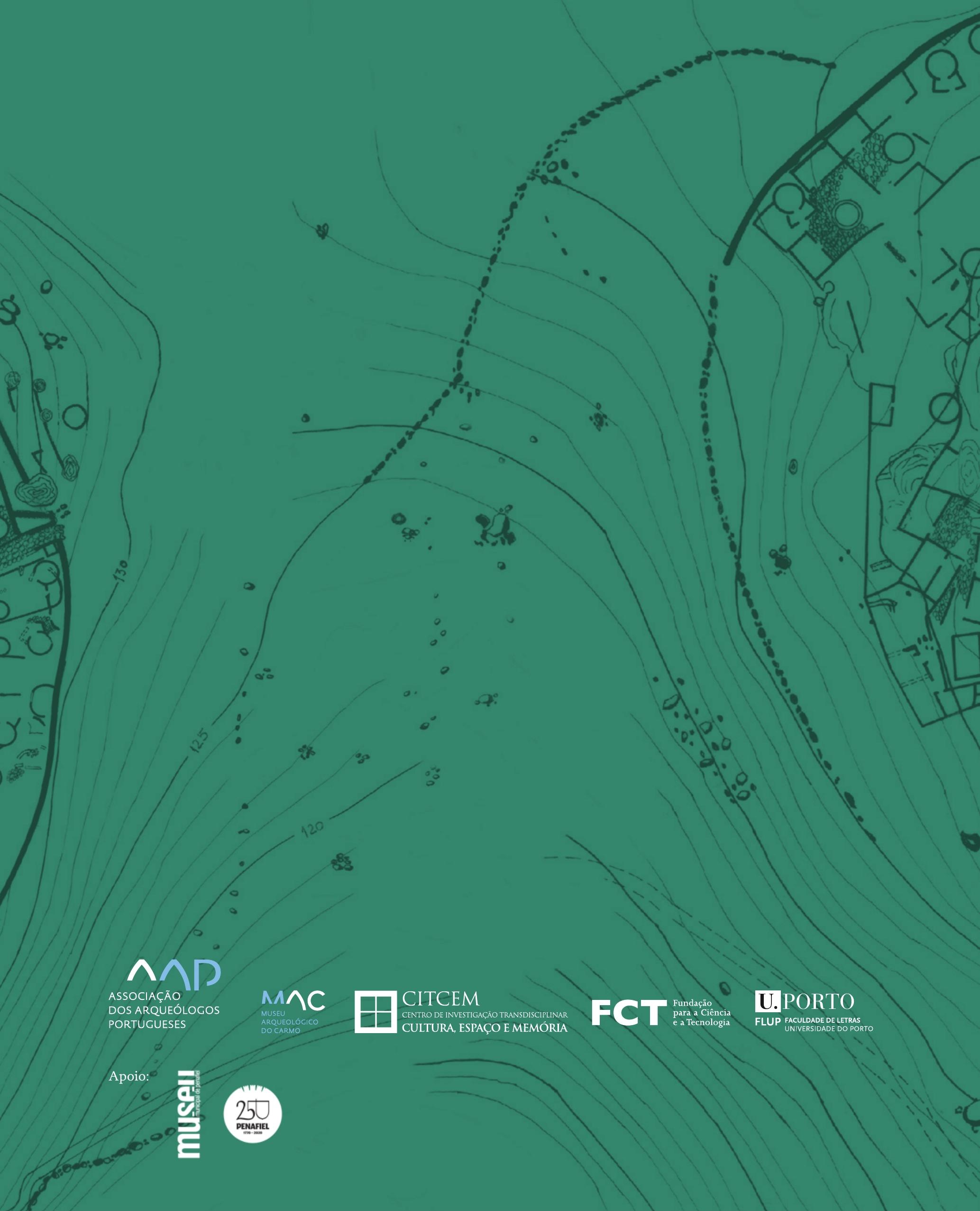

